\title{
1The effect of grain size on carbonate contaminant removal from tooth enamel: 2towards an improved pretreatment for radiocarbon dating 3
}

4Rachel Wood ${ }^{1}$, Mathieu Duval ${ }^{1,2}$, Nguyen Thi Mai Huong ${ }^{3}$, Nguyen Anh Tuan ${ }^{3}$, Anne5Marie Bacon ${ }^{4}$, Fabrice Demeter ${ }^{5}$, Philippe Duringer ${ }^{6}$, Marc Oxenham ${ }^{7}$, Philip Piper ${ }^{7}$ 6

$7^{1}$ Research School of Earth Sciences, The Australian National University, Canberra, 82601, Australia

$9^{2}$ Centro Nacional de Investigación sobre la Evolución Humana (CENIEH), Burgos, 10Spain

$11^{3}$ Anthropological and Palaeoenvironmental Department, The Institute of Archaeology 12of Vietnam, Hanoi, Vietnam

$13^{4}$ UMR 5288 du CNRS, AMIS Anthropologie Moléculaire et Imagerie de Synthèse, 14Faculté de chirurgie dentaire, Montrouge, France.

$15^{5}$ Département Homme Nature Société, UMR 7206 du CNRS, Muséum National

16d'Histoire Naturelle, Musée de l’Homme, Paris, France.

$17^{6}$ Ecole et Observatoire des Sciences de la Terre, Institut de Physique du Globe de 18Strasbourg, UMR 7516 du CNRS, Université de Strasbourg, Strasbourg, France. $19^{7}$ School of Archaeology and Anthropology, The Australian National University, 20Canberra, 2601, Australia

\section{1}

22Corresponding author: rachel.wood@anu.edu.au

\section{3}

\section{Abstract}

25

26It is rarely possible to directly radiocarbon date skeletal remains from hot 27environments as collagen rapidly degrades. Although able to survive in the majority 28of burial environments for longer, unburnt biological apatites frequently produce 29inaccurate radiocarbon dates due to contamination from carbonate in the groundwater. 30The location of this contamination within the skeletal material is rarely investigated, 31 hampering development of improved methods. This paper focuses on tooth enamel 32 and aims to test whether carbonate contaminants are sitting at the crystallite 33boundaries, and from this to test a pretreatment to produce more accurate radiocarbon 34age estimates. Although the porosity of enamel is low, trace elements are known to 35diffuse between enamel prisms and crystallites. Gordon et al. (2015, Science, 347 36(6223), 746-750) identified magnesium substituted amorphous calcium phosphate 37between the apatite crystallites. This phase contains the majority of magnesium within 38modern rodent enamel, providing an opportunity to monitor its removal, and thus 39 carbonate contaminants sitting between or on the surface of the crystallites. Modern 40Sus scrofa enamel and four ancient Sus scrofa teeth have been used to demonstrate 41that the more finely ground the enamel, the more magnesium can be removed with an 42acetic acid leach, and the more accurate the radiocarbon dates. After leaching in acetic 43acid, teeth dating to beyond the limit of the radiocarbon method (c.50 ka) produce 44ages of c.20 kBP when hand ground, and c.30 kBP when mechanically ground. This 45suggests that some contaminants are sitting at the crystallite boundaries. However, 
46although mechanically grinding substantially increases the amount of carbonate 47contamination removed in an acid leach compared to hand grinding, not all 48contaminants could be removed from the samples examined in this study, and 49radiocarbon dates on tooth apatite should still be regarded as minimum ages. 50

\section{Key words}

52Radiocarbon; Dating; Enamel; Teeth; Diagenesis; Stable isotope 53 


\section{Introduction}

55

56Bone, dentine and enamel are made of varying proportions of organic, primarily 57 protein, mineral and water phases. The protein fraction is normally targeted when 58radiocarbon dating skeletal remains. A variety of cleaning protocols, or 59'pretreatments', that effectively remove contaminants have been developed over 60several decades of intensive research (Brown et al., 1988; Longin, 1971; Marom et al., 612012; McCullagh et al., 2010; Ramsey et al., 2004; Stafford Jr et al., 1988; Tisnérat62Laborde et al., 2003). However, in warm environments collagen rapidly degrades and, 63if water is present, leaches out of bone and dentine (Collins et al., 2002; Hedges, 642002). As a result, in these environments it is rarely possible obtain sufficient collagen 65to accurately radiocarbon date skeletal material beyond a few thousand years (Calo et 66al., 2015; Storm et al., 2013; Wood et al., 2013; Zazzo et al., 2014). Without the 67ability to directly date skeletal remains, it is exceptionally difficult to create high 68 quality chronologies for e.g. cemetery sites or the domestication of fauna.

69

70The mineral component of bone and enamel, bioapatite, out-survives collagen in the 71majority of deposition environments. Although it can preserve stable isotopic 72signatures for more than 1 ma (Lee-Thorp, 2002), radiocarbon age estimates are 73normally found to be younger than expected. Within the Holocene, dates on bioapatite 74normally underestimate the expected age of a sample by a few hundred ${ }^{14} \mathrm{C}$ years, but 75in the Pleistocene this can increase to 10,000 s ${ }^{14} \mathrm{C}$ years (Grün et al., 1997; Haynes, 761968; Hedges et al., 1995; Zazzo, 2014; Zazzo et al., 2013; Zazzo and Saliège, 2011). 77

78Enamel has long been thought to provide a more reliable material for radiocarbon 79dating than bone apatite (Haynes, 1968) because it has lower porosity and a smaller 80surface area (Hedges et al., 1995; Millard and Hedges, 1996), larger crystallites (26.3 81x 100-1000 nm vs. 5 x $100 \mathrm{~nm}$ (Bottero et al., 1992; Cui and Ge, 2007)), and is less 82soluble due to its lower carbonate content (3.5 wt\% vs. 6 wt\% (Elliott, 2002)). Despite 83these observations, relatively few studies have focused on radiocarbon dating enamel. 84When Zazzo (2014) reviewed the limited data and added several extra case studies he 85 found that when bone and enamel apatite were pretreated in a similar manner, they 86underestimated the age of the samples to a similar extent, and he concluded that they 87 are equally poor materials for radiocarbon dating.

88

89However, enamel has a complex hierarchical structure which is quite different to that 90of bone. Does this mean that contamination could be more effectively removed from 91enamel if it were pretreated in a different way to bone? This paper aims to consider 92the effect of enamel structure on the potential diagenetic pathways which could add 93exogenous carbonate to tooth enamel, and investigate whether a better understanding 94of one of these pathways may enable more accurate radiocarbon dates to be produced. 95

961.1 The structure of tooth enamel

97Tooth enamel consists of an inorganic mineral phase, the focus of this study, with a 
98small proportion of organic material ( $<1 \%$ (Lee-Thorp, 2002)) and water. In 99mammals, the inorganic phase consists of crystallites of bioapatite (human: 26.3 x 68 100x 100-1000 nm (Cui and Ge, 2007)) arranged into micrometer-sized prisms (also 101 known as rods) which are woven into various structures through the enamel cross102section (known as the schmelzmuster). Between the prisms, crystallites are arranged 103into an interprismatic matrix (terminology follows Koenigswald and Sander (1997), 104figure 1).

105

106The crystallites are formed of hydroxyapatite, also known as bioapatite, with the 107general formula $\mathrm{Ca}_{10}\left(\mathrm{PO}_{4}\right)_{6} \mathrm{OH}_{2}$, into which various ions are substituted. Carbonates 108can be located in a number of environments within the apatite phase. Most carbonate 109is found in the B position, substituting for phosphate, with some found in the A 110position, substituting for hydroxyl ions, and the remaining in as yet poorly defined 111environments (Elliott, 1994). Several early studies proposed that non-apatite mineral 112phases may also be present in enamel (Driessens, 1982; Driessens and Verbeeck, 1131982, 1985; Hallsworth et al., 1972), and in 2015 Gordon et al. demonstrated that 114 magnesium is concentrated between crystallites in non-pigmented rodent enamel. 115They suggested this was contained in a magnesium substituted amorphous calcium 116phosphate (Mg-ACP). In rodent enamel, the Mg-ACP phase contains carbonate, and 117at crystallite junctions the concentration of carbonate is higher than in the apatite 118(Gordon and Joester, 2015). The chemical location of carbonate within this phase is 119 not yet known.

120

121Although enamel porosity is low, pores are present and play an important role in the 122diffusion of water and solutes through the tooth (Shellis and Dibdin, 2000). Pores 123exist both between prisms and within prisms (Shellis and Dibdin, 2000). In agreement 124 with this model, desorption-adsorption studies with water suggest pore sizes in human 125molar enamel follow a double-peaked distribution with maxima at $1 \mathrm{~nm}$ and $2.5 \mathrm{~nm}$ 126(Zahradnik and Moreno, 1975). Porosity also varies throughout a tooth and between 127teeth: enamel density decreases from the outer enamel surface (OES) to the enamel 128dentine junction (EDJ), and tends to be lower in molar than canine enamel due to 129differences in prism packing (Shellis and Dibdin, 2000). Finally, larger pores in the 130 form of spindles (the remains of odontoblast processes that become trapped when 131enamel formation begins) and tufts (thin, branching features high in protein) extend 132 from the EDJ into the inner enamel.

133

1341.2 Enamel diagenesis and the addition of carbonate

135Carbonate from groundwater is likely to enter the tooth structure in three ways. First 136secondary minerals such as calcite can form (Haynes, 1968), most likely on the 137surface or in the cracks. Second, it is possible for apatite to recrystallize in a mid-high $138 \mathrm{pH}$ solution (Larsen and Jensen, 1989). However, it is likely that recrystallized apatite 139 will contain less carbonate than the original bioapatite (LeGeros and Tung, 1983), as 140incorporation of carbonate increases solubility of hydroxyapatite (Grøn et al., 1963; 141LeGeros and Tung, 1983) due to the increased strain in the crystal lattice (Blumenthal 
142et al., 1975). This would reduce the importance of this mechanism for radiocarbon 143dating.

144

145Finally, it is likely carbonate diffuses through enamel. Several models have been built 146to explain the diffusion of trace elements within the burial environment (Kohn, 2008; 147Millard and Hedges, 1996), and a diffusion-adsorption mechanism is thought to 148explain the diffusion of uranium into enamel as employed in U-series dating (Millard 149and Hedges, 1996). Enamel is an imperfect semi-permeable membrane, which acts as 150a molecular sieve (Borggreven et al., 1980; Borggreven et al., 1977; Shellis and 151Dibdin, 2000), and is permeable to water, ions and small organic molecules (Shellis 152and Dibdin, 2000). Most diffusion occurs at the prism boundaries (Brudevold et al., 1531977; Lindén, 1968) where the largest pores are found (Shellis and Dibdin, 2000), but 154it has also been observed to a more limited extent within the prisms between 155crystallites in modern teeth (Lindén, 1968). Gordon and Joester (2015) suggest 156diffusion may also be possible through the hydrated Mg-ACP phase at room 157temperature and pressure, although further work is needed to clarify this.

158

1591.3 Radiocarbon dating of enamel

160The standard radiocarbon pretreatment applied to both bone and enamel apatite 161involves leaching in acetic acid under vacuum (Balter et al., 2002; Haynes, 1968; 162Zazzo and Saliège, 2011). This treatment was designed to remove calcite, which is 163more soluble than hydroxyapatite in acetic acid (Haynes, 1968), but it is also likely to 164remove at least some of the Mg-ACP phase (Gordon et al., 2015) and the more 165soluble apatite high in carbonate (LeGeros and Tung, 1983; Zazzo and Saliège, 2011). 166Unfortunately the latter is more likely to be original bioapatite than recrystallized 167material (Sillen and LeGeros, 1991).

168

169There is little consistency between laboratories in the conditions under which this 170leaching occurs. Shorter leaching times (around an hour) are favoured by some 171researchers (Lee-Thorp and van der Merwe, 1991) as brushite $\left(\mathrm{CaHPO}_{4} \cdot 2 \mathrm{H}_{2} \mathrm{O}\right)$ can 172precipitate below pH4 (Larsen and Jensen, 1989). However, where acid leaching 173occurs under vacuum (Balter et al., 2002) the formation of brushite is unlikely to 174affect the radiocarbon age, leading others to advise reaction times of at least 10 hours 175(Zazzo and Saliège, 2011). Both acetic acid (Haynes, 1968) and hydrochloric acid 176(Van Strydonck et al., 2009) have been used at varying concentrations to clean 177bioapatites, and there is little conclusive data to suggest which might be better. In 178contrast to these continuing conversations, Zazzo (2014) has demonstrated that a grain 179size of $<160 \mu \mathrm{m}$ produces older age estimates than a grain size of $>1 \mathrm{~mm}$, although 180even with the smaller grain size, dates are not accurate.

181

182The ability of step-heating to improve age estimates of bone 183(Haas and Banewicz, 1980) and, of more interest here, enamel (Surovell, 2000) has 184also been investigated. When an acid leach was used prior to heating, accurate dates 
185were obtained. Unfortunately, the temperature required to remove contaminants was 186not consistent between samples, hindering wider application of this technique. 187

188The effect of grain size on age and the ability of preheating to aid contaminant 189removal suggests that that much of the carbonate not removed with the current acid 190leaching protocol in enamel may sit within the enamel structure rather than on the 191surface, and could be related to the diffusion and adsorption of carbonate. The 192experiment reported here aimed to examine whether enamel could be broken into 193individual crystallites so their surface could be removed with an acid leach, and 194subsequently whether age was related to Mg content, and thus presence of the Mg195ACP phase. If carbonate contaminants are located at the crystallite boundaries, either 196in the Mg-ACP or on the crystallite surface, Mg should decrease with F14C (the 197fraction ${ }^{14} \mathrm{C}$ in the sample divided by the fraction ${ }^{14} \mathrm{C}$ in the standard, $\delta^{13} \mathrm{C}$-normalised 198(Reimer et al., 2004)).

199

\section{Materials and methods}

201

2022.1 Samples

203This study used enamel from Sus scrofa $2^{\text {nd }}$ or $3^{\text {rd }}$ molars to avoid variations resulting 204 from differences in enamel structure and chemistry between species and teeth. These 205large teeth have thick enamel, and are abundant in a range of geographic and 206deposition environments. Sus $3^{\text {rd }}$ molars are also of considerable archaeological 207interest as they can be readily used to identify not only the species but also provide 208information about the impact and process of domestication (Cucchi et al., 2009; Evin 209et al., 2015).

210

211One modern M3 was used to determine grinding and acid leach conditions, and to 212examine how magnesium content was affected by pretreatment (Table 1). The sample 213was the result of natural death from a piggery near Byron Bay (New South Wales, 214Australia). The maxilla BB1 was left near or on the surface and collected defleshed.

215

216Four ancient samples were collected (Table 1). Three are from the sites of Duoi U'Oi 217(sample DU795) and Lang Trang (samples LT1 and LT4), two caves in tower karsts in 218humid subtropical northern Vietnam, and date to beyond the limit of the radiocarbon 219 method. Given their age, these are highly sensitive to young contaminants. One 220sample was recovered from a well-dated Holocene site, Rach Nui, an artificial mound 221 in the tropical savanna of southern Vietnam.

222

223An assemblage of faunal remains was recovered from a breccia in Duoi U'Oi (Man 224Duc village, c. 85 km SW Hanoi) in 2003 (Bacon et al., 2008; Bacon et al., 2015). Sus 225 scrofa teeth are common (86 $1^{\text {st }}, 2^{\text {nd }}$ or $3^{\text {rd }}$ permanent molars) and a speleothem found 226towards the top of the bone bearing breccia has been dated by U-series to $66 \pm 3 \mathrm{ka}$. 227Sus scrofa are the most frequent fossil (NISP 1027 (Long et al., 1996)) in Cave 2, 228Breccia 5 at Lang Trang (c.125 km SW Hanoi), excavated in 1989 (Ciochon and 
229Olsen, 1991). Although preliminary electron spin resonance dates have been produced 230from Cave 2 (285 \pm 24 ka (Ciochon and Olsen, 1991)), finalized results and their 231relationship to the cave stratigraphy have not been published. In contrast, on 232biostratigraphic grounds, the assemblage is thought to be of a similar age to that in 233Duoi U’Oi, dating between 80 - 100 ka (Long et al., 1996). If confirmed by U-series 234to date beyond $50 \mathrm{ka}$, any ${ }^{14} \mathrm{C}$ in the teeth from Duoi U'Oi and Lang Trang can be 235regarded as a contaminant.

236

237Rach Nui is located in Long An Province, around $50 \mathrm{~km}$ south of Ho Chi Minh City 238(Oxenham et al., 2015). It is an artificial mound, resulting from construction and 239reconstruction of at least 14 house platforms, rising $5-6 \mathrm{~m}$ above the surrounding 240alluvial landscape today. The sampled Sus scrofa M2 was excavated in 2012 from an 241exterior surface constructed of silty clay sediments packed with pottery and domestic 242waste such as shell and bone. A radiocarbon chronology based on charcoal has been 243established, suggesting that the mound was constructed in 45 - 210 calibrated years 244(95.4\% probability, against IntCal13 (Reimer et al., 2013)). The upper limit of the 245 context sampled here is poorly constrained, but the overall sequence of deposits is 246well dated and demonstrates no reworking and little inbuilt age in the charcoal dated. 247A date on charcoal from the unit falls between 3550 - 3360 cal BP (SANU-30823, $2483200 \pm 35$ BP, Oxenham et al., 2015).

249

2502.2 U-series dating

251The teeth from Duoi U'Oi and Lang Trang were U-series dated to confirm that they 252 fell beyond the limit of radiocarbon dating. Laser ablation U-series analyses were 253carried out at the Research School of Earth Sciences of the Australian National 254University (ANU), using a custom-built laser sampling system interfaced between an 255ArF Excimer laser and a MC-ICP-MS Finnigan Neptune (for details, see Eggins et al., 2562003; Eggins et al., 2005), following principles and procedures described in Grün et 257al. (2014). Cross sections were cut from each tooth sample and several spots were 258ablated across at least two transects per tooth (figures 2 and 3) to evaluate the spatial 259 variability of uranium-series isotopes in both enamel and dentine dental tissues.

260Individual closed system U-series age estimates were calculated for each ablation 261 spot, although values for which U-concentration is lower than $0.5 \mathrm{ppm}$ should be 262considered with caution. For each dental tissue, final U-series age results were 263calculated by integrating the data from all the spots of a given tissue.

264

2652.3 Sample pretreatment for radiocarbon

266The dentine and enamel surface, including the surface of cracks, was removed with a 267dremel drill and tungsten carbide drill bit. Teeth were then ground by hand, first by 268 crushing in a hardened steel hammer press, and then under MilliQ ${ }^{\mathrm{TM}}$ water in an agate 269pestle and mortar until smooth to touch (around 15 minutes). Samples were freeze270dried, and subdivided. 
272Lee-Thorp et al. (1997) have noted that small particle sizes can be generated with a 273diamond drill. Unfortunately it was not possible to remove the large sample size 274required in this study with a drill so a McCrone ${ }^{\mathrm{TM}}$ Microniser was used to 275 mechanically grind the samples.

276

2770ne aliquot of hand ground material was retained, whilst the remaining material was 278further ground with the microniser. Prior to use and between samples, agate beads and 279the plastic container were soaked in dilute $\mathrm{HCl}$ and then $\mathrm{MilliQ}^{\mathrm{TM}}$ water. To determine 280the length of grinding required to separate the crystallites, a series of c.1g aliquots of 281the modern tooth enamel were ground for 5, 15 and 30 minutes in $5 \mathrm{ml} \mathrm{MilliQ^{ \textrm {TM } }}$ 282 water, and freeze-dried. Ancient samples were ground for 30 minutes in $5 \mathrm{ml} \mathrm{MilliQ}{ }^{\mathrm{TM}}$ 283water.

284

285Acetic acid leaching followed a protocol similar to that outlined in Zazzo (2011). The 286sample was weighed into a Vacutainer ${ }^{\mathrm{TM}}$ and placed under a weak vacuum (c.1x10 ${ }^{-2}$ 287Torr) prior to the addition of $1 \mathrm{ml}$ unbuffered $1 \mathrm{M}$ acetic acid per $50 \mathrm{mg}$ enamel with a 288gas tight syringe. After $30 \mathrm{~min}$ and 1 hour, evolved gas was removed by freezing the 289 solution in a dry-ice/ ethanol slush, and evacuating until a vacuum of c. $1 \times 10^{-2}$ Torr 290was obtained. The modern sample was leached for 15 minutes, 1, 8, 20, 44 and 71 291hours. Ancient samples were leached for 20 hours. After rinsing five times in 292MilliQ ${ }^{\mathrm{TM}}$, samples were freeze-dried and, to avoid possible adsorption of atmospheric $293 \mathrm{CO}_{2}$, stored under a weak vacuum in an Exetainer ${ }^{\mathrm{TM}}$ until radiocarbon measurement. 294To assess yield reproducibility, acid leaching of one sample of ground enamel 295(BB1_M15_1 hour) was repeated three times giving a standard deviation of $\pm 0.6 \%$. 296

2972.4 Radiocarbon dating

298c. $42 \mathrm{mg}$ of enamel was reacted with $5 \mathrm{ml}$ 85\% phosphoric acid in a Vacutainer $^{\mathrm{TM}}$ 299 evacuated to $<3 \times 10^{-3}$ Torr. The resulting carbon dioxide was cryogenically purified 300and collected before graphitization with hydrogen over an iron catalyst and 301measurement in an NEC single stage accelerator at the Research School of Earth 302Sciences at the ANU (Fallon et al., 2010). Dates have been corrected using the $\delta^{13} \mathrm{C}$ 303measured by AMS and calculated according to Stuiver and Polach (1977).

304

305To examine whether carbon was added during pretreatment and radiocarbon dating, a 306 mixture of geological apatite (purchased from Awaken Crystals ${ }^{\mathrm{TM}}$ ) and either marble 307(IAEA-C1) or a modern oyster shell was used to simulate ancient and modern enamel 308respectively with $0.7 \% \mathrm{C}$. As the carbonate would completely dissolve during the 309acetic acid leach, the apatite was ground and pretreated, and the carbonate added 310immediately prior to dating. No uncontaminated, known age ancient enamel sample 311suitable for use as a radiocarbon blank standard is known. Therefore, although not a 312perfect substitute for enamel, this mixture was thought the best substitute possible, 313having a broadly similar composition and therefore surface area as enamel. 
315The dates from Rach Nui have been calibrated against IntCal13 (Reimer et al., 2013) 316in OxCal v.4.2 (Ramsey, 2009) for comparison to the dates presented by Oxenham et 317al. (2015).

318

3192.5 Field emission scanning electron microscopy (FESEM) 320Scanning electron microscopy was undertaken to examine grain size. To break the 321 aggregates of highly electrostatic nanoparticles, ground samples were suspended by 322ultrasonicating in water for 30 min and pipetted onto super smooth silicon mounts 323(Agar Scientific ${ }^{\mathrm{TM}}$ ) prior to analysis without coating. Secondary electron images were 324collected using a Zeiss UltraPlus analytical FESEM housed in the Centre for 325Advanced Microscopy at the ANU. An accelerating voltage of $1-2 \mathrm{kV}$, a working 326 distance of $1.6-2.3 \mathrm{~mm}$, and an aperture of $30 \mu \mathrm{m}$ were used.

327

3282.6 Inductively Coupled Plasma - Atomic Emission Spectrometry (ICP-AES) $32910 \mathrm{mg}$ of enamel was dissolved in $10 \mathrm{ml}$ 2\% distilled nitric acid for analysis of 330magnesium content on a Varian Vista AX CCD Simultaneous ICP-AES using 331AccuTrace mixed element standards at the Research School of Earth Sciences at the 332ANU. The detection limit for $\mathrm{Mg}$ was $0.05 \mathrm{mg} / \mathrm{L}$, and the standard deviation of the 333three leached aliquots of M15_1 was $0.06 \mathrm{mg} / \mathrm{L}$ or $0.003 \mathrm{wt} \% \mathrm{Mg}$. Three blanks 334 contained $0.00 \mathrm{mg} / \mathrm{L}$.

335

3362.7 Fourier Transform-Infra Red spectroscopy (FTIR)

337FTIR was undertaken to check for brushite formation, which although unlikely to 338affect the radiocarbon age, would affect element ratios and stable isotope analyses. 1$3391.5 \mathrm{mg}$ of sample was mixed with 200-300 mg dry $\mathrm{KBr}$ and pressed into pellets under 340vacuum. The average of 100 transmission spectra were recorded on a Bruker Tensor 34127 at the Research School of Earth Sciences at the ANU between $-400--4000 \mathrm{~cm}^{-1}$, at 342a resolution of $4 \mathrm{~cm}^{-1}$. Brushite was identified by a band at $-525 \mathrm{~cm}^{-1}$ resulting from a $343 v_{4}$ PO bend (Berry and Baddiel, 1967; Petrov et al., 1967). Reproducibility was 344determined through repeat measurement of one ground aliquot (M5) and repeat 345leaching of one sample (M15_1).

346

347It was not possible to use the spectra to investigate changes in the carbonate 348environment. The carbonate $\mathrm{v}_{2}$ bands of most interest (Fleet, 2009; Yi et al., 2014) 349 overlap with each other and the strong phosphate $v_{3}$ band. In FTIR spectra band width, 350 and therefore the amount of overlap between bands, is affected by grain size (Hunt 351and Vincent, 1968). This made comparisons between the hand ground and micronised 352samples sensitive to methods used to subtract the overlapping phosphate band, and 353confident interpretations could not be made.

354

3552.8 Gas Bench-Isotope Ratio Mass Spectrometry (GB-IRMS)

$356 \delta^{13} \mathrm{C}, \delta^{18} \mathrm{O}$ and $\% \mathrm{C}$ were measured by GB-IRMS at the Research School of Earth 357Sciences at the ANU. $22 \mathrm{mg}$ enamel was reacted with $3 \mathrm{ml} 99 \% \mathrm{H}_{3} \mathrm{PO}_{4}$ in an 358 Exetainer $^{\mathrm{TM}}$ and analysed on a Gas Bench connected to a Sercon 20-22 isotope ratio 
359mass spectrometer operating in continuous flow mode. An internal carbonate 360reference and NBS18 was used to scale the data. Reproducibility (1 standard 361deviation) assessed by repeat measurement of the internal standard, repeat 362measurement of one ground aliquot (M5) and repeat leaching of one sample (M15_1) 363was $0.001 \%$ for $\delta^{13} \mathrm{C}, 0.2 \%$ for $\delta^{18} \mathrm{O}$ and 0.01 for $\% \mathrm{C}$. $\delta^{13} \mathrm{C}$ reproducibility is 364 typically around $0.1 \%$, and appears unusually low here.

365

\section{Results}

367

3683.1 Modern enamel

369

3703.1.1 Effect of grinding protocols on grain structure

371As found previously (Frazier, 1970), imaging of ground enamel is hindered by the 372 strongly electrostatic nature of the nano-sized crystallites. Even after ultrasonication 373the crystallites tended to clump together which, combined with the large range in 374particle size, made quantification of grain size difficult. However, the images in figure 3752 illustrate how the grinding protocols separated the components of enamel. When 376 ground by hand, enamel prims were separated. These appear to have remained largely 377intact with widths around $1 \mu \mathrm{m}$ (figure 4a-b) although a few crystallites were liberated 378(figure 4c). Mechanical grinding increased the proportion of free crystallites (figure 3794d). When large clumps were observed, they were composed of agglomerates of 380individual and broken crystallites (figure 4e). However, after 30 minutes grinding 381 sections of prism around $0.5 \mu \mathrm{m}$ in width remain (figure 4f). Although significantly 382better at breaking the prism structure than hand grinding, the McCrone Microniser 383was not able to separate all crystallites.

384

\subsubsection{Effect of acid leaching on $\mathrm{Mg}$ content}

386Samples leached for longer than 20 hours contained brushite (table 2), and are not 387discussed further. In the remaining samples there is a clear relationship between 388grinding time and magnesium content in the acid leached enamel (figure 5a). During 389the first 15 minutes of leaching there is a rapid decrease in $\mathrm{Mg}$, after which time 390concentration gradually declines. Concentration of $\mathrm{Mg}$ is also dependent on grain 391size, with the samples ordered in terms of length of micronisation for each acid leach. 392After 20 hours in acetic acid the hand ground sample contained $0.128 \mathrm{wt} \% \mathrm{Mg}$, whilst 393the sample micronised for 30 minutes contained $0.099 \mathrm{wt} \% \mathrm{Mg}$.

\section{4}

395This pattern is not due to the faster reaction of the smaller grain sizes as the \% yield 396for all leached samples was between 60 - 70 \% (table 2). Neither is it due to the 397 formation of large quantities of brushite (table 2). This suggests that the smaller the 398grain size, the more Mg-ACP is removed. For the conditions examined here, enamel 399 ground for 30 minutes in the microniser and leached for 20 hours is likely to remove 400the most Mg-ACP.

401

4023.1.3 Effect of acid leaching on $\delta^{13} \mathrm{C}, \delta^{18} \mathrm{O}$ and $\% \mathrm{C}$ 
403The majority of change within the IRMS data occurs during the first hour of acetic 404acid leaching (table 2, figure $6 \mathrm{a}-\mathrm{c}$ ). $\delta^{13} \mathrm{C}$ ranges by just $0.017 \%$, the majority of the 405range being caused by an unusually high value for M15. Although outside of the 406reproducibility of the batch, this is a tiny variation in contrast to a typical 407measurement error of c.0.1\%. Therefore although the smaller grain sizes are most 408depleted during the leaching process, perhaps suggesting that the carbonate in the Mg409ACP phase has a different isotopic value to carbonate within the apatite, further 410replication is required to confirm the pattern. $\delta^{18} \mathrm{O}$ ranges by $1.6 \%$, increasing in the 411 first hour of leaching, but there is no systematic difference between grain sizes. \%C 412ranges by $0.1 \% \mathrm{C}$, around $15 \%$ of the starting carbon concentration. Overtime the $413 \% \mathrm{C}$ gradually decreases with the exception of a rapid decrease at 15 minutes, 414 followed by increase at 1 hour. Again, there seems no systematic difference between 415the different grain sizes.

416

4173.2 Ancient enamel

418

4193.2.1 U-series dating

420Because dental tissues are known to behave as open systems for U-series elements, U421series results should be considered as minimum possible age estimates for the fossil 422remains (Grün et al., 2014). In the three tooth samples, ablation spots show U423concentration values decreasing from the dentine-enamel junction towards the outer 424enamel surface (which is virtually free of uranium), suggesting a preferential direction 425of uranium diffusion into the enamel layer from the dentine. Such a trend is not 426surprising, as it is might simply be related to the density gradient, which increases 427 from the enamel dentine junction to the outer enamel surface (see section 1.1.).

428Although U-concentrations values measured in the enamel and dentine of sample 429DU795 differ by at least one order of magnitude (figure 2), U-series ages are spatially 430highly consistent, with integrated results of around 100-110 ka for all dental tissues 431(table 3).

432In contrast, data collected for Lang Trang samples (LT1 and LT4, figure 3) are much 433more scattered. U-concentration values measured in dentine of LT1 are overall 434spatially constant around 6-7 ppm, while U-series data are close to secular 435equilibrium, explaining the relatively large age errors. These results indicate that the 436dentine is older than $350 \mathrm{ka}$. In comparison, enamel U-series ages are around 210-240 $437 \mathrm{ka}$, although the very low concentration values induce a large uncertainty for LT1438EN1 (table 3).

439In comparison, sample LT4 shows much younger U-series ages. The two dentine 440domains (DE1 and DE3) show highly consistent results of 115-120 ka, while the 441enamel domains have more scattered values, mostly because of the very low U442 concentration values ( $<0.5 \mathrm{ppm})$. Consequently, no integrated age results were 443obtained for enamel domains EN1 to EN3 (table 3). 
444To summarise, the U-series dating results confirm that the three teeth from Duoi U'Oi 445and Lang Trang fall beyond the time range covered by the radiocarbon dating method.

\section{6}

4473.2.2 Effect of acid leaching on Mg content

448To examine the effect of the acetic acid leach and grain size, four aliquots of the 449ancient teeth were examined. Each sample was hand ground and a subsample

450micronised for 30 minutes. A subsample of both hand ground and micronised aliquots 451 was leached in acetic acid for 20 hours. It was not possible to leach a hand ground 452aliquot of ISO-6 due to the limited sample size.

453

454Despite careful washing of the grinding equipment, LT1 must have been contaminated 455during mechanical grinding as the Mg concentration is higher in the micronised than 456hand ground aliquot (table 4, figure 5b). Excluding this one data point, the samples 457 follow the same trend as the modern enamel. As with the modern enamel, the hand 458ground sample contains the most $\mathrm{Mg}$ whilst the leached micronised sample contains 459the least. Although the hand ground Pleistocene samples (0.13-0.16 \% Mg) contain 460less $\mathrm{Mg}$ than the modern $(0.23 \% \mathrm{Mg})$ and Holocene $(0.25 \% \mathrm{Mg})$ enamel, all contain 461 similar concentrations after leaching $(0.10-0.13 \% \mathrm{Mg})$. Interestingly, the Holocene 462sample ISO-6 contained much less $\mathrm{Mg}$ when mechanically ground $(0.15 \% \mathrm{Mg})$ than 463hand ground $(0.25 \% \mathrm{Mg})$, perhaps suggesting leaching of the Mg-ACP phase started 464during mechanical grinding in water.

465

466In contrast to the modern enamel, consistently more hand ground material survived 467the acid leach than the micronised sample (table 4), and a small amount of brushite 468may be present in LT4 (table 4). Though not as clear as in the modern enamel, these 469results are suggestive of preferential removal of the Mg-ACP phase.

470

4713.2.3 Effect of acid leaching on $\% C, \delta^{13} \mathrm{C}$ and $\delta^{18} \mathrm{O}$

472The differences in \%C and carbonate isotopes between the leached hand and leached 473 micronised aliquots seen in the modern tooth are accentuated in the ancient samples 474(figure 6d-f, table 4), particularly in the micronised samples. For example, in the 475 micronised samples, $\% \mathrm{C}$ decreases by up to $0.2 \% \mathrm{C}, \delta^{18} \mathrm{O}$ by more than $2 \%$ whilst $476 \delta^{13} \mathrm{C}$ decreases by up to $1.4 \%$ during the acetic acid leach. The large difference in \%C 477is partially related to carbon contamination added to the micronised sample, as 478discussed further in the radiocarbon section below, although leached micronised 479samples have around 0.1 less \%C than leached hand ground samples. The larger 480changes occurring within ancient samples compared with the modern tooth is likely to 481be due to the effect of diagenesis in the ancient teeth, and the removal of exogenous 482contamination. However, with only one modern tooth examined and no understanding 483of variability between teeth of the same taxa, further work would be needed to 484 confirm this.

485

4863.2.4 Effect of acid leaching on radiocarbon age 
487It appears that carbon contamination was introduced to all samples whilst 488mechanically grinding, as micronised samples have a higher F14C and more carbon 489than hand ground samples (figure 7, table 4). This contamination was identified in the 490mixture of geological apatite and marble used to monitor laboratory backgrounds 491(figure 8). Although mixtures of apatite and modern oyster shell are consistent 492throughout treatment, the mixtures of marble and micronised apatite have higher 493F14C values than the mixture of marble and hand ground apatite. This suggests that 494around $1.6 \pm 0.05 \%$ of the carbon within the micronised sample was a modern 495 contaminant, most likely atmospheric carbon adsorbed to the large surface area. 496However, when the apatite was leached in acetic acid for 20 hours, the contamination 497is removed. A larger amount of modern contamination was added to the ancient 498enamel samples (between $3.8-5.7 \%$ ), presumably due to a larger surface area of the 499needle shaped enamel grains compared to the more spherical geological apatite grains. 500 However, it is thought likely that the acetic acid removed this contamination, and so 501all ancient enamel samples have had a laboratory blank calculated from the laboratory 502long-term marble average subtracted, as routine practice for carbonates dated at the 503ANU.

\section{4}

505All acid leached micronised samples contained less ${ }^{14} \mathrm{C}$ than acid leached hand ground 506samples, and F14C is related to Mg concentration (figure 9). In terms of conventional 507radiocarbon age (figure $7 \mathrm{~b}$ ), untreated hand ground Pleistocene samples had ages of 508around $15 \mathrm{kBP}$, leached hand ground samples around $20 \mathrm{kBP}$ and leached 509 mechanically ground samples around $30 \mathrm{kBP}$.

510

511Age differences were much smaller in the more recent tooth from Rach Nui. The 512leached mechanically ground aliquot was around 400 years older than the starting 513material. The calibrated range of the mechanically ground and leached sample 514overlaps at $95.4 \%$ probability with a fragment of charcoal from the same 515 archaeological context and the two conventional ages pass a Chi squared test $\left(\mathrm{X}^{2}\right.$ Test: $516 \mathrm{df}=1, \mathrm{~T}=2.4$ (5\% 3.8)). Unfortunately the sample was too small to radiocarbon date 517a leached hand ground aliquot to assess whether mechanical grinding prior to acetic 518acid leaching improved the age estimate in comparison to grinding the sample by 519hand.

520

\section{Discussion}

522

523It has been known for some time that magnesium is preferentially removed during 524acid dissolution of enamel powder (Borggreven et al., 1986) and in early carious 525enamel lesions (Hallsworth et al., 1972). This formed the basis for early hypotheses 526that enamel was not only formed of apatite, but contained a second mineral phase. 527Using modern enamel this study has demonstrated that the amount of magnesium 528removed with acetic acid is dependent upon grain size, as would be expected if the 529 majority of magnesium within in enamel is located at the crystallite boundaries, either 530in Mg-ACP or on the crystallite surface. 


\section{1}

532 When replicated with ancient enamel, radiocarbon age is found to be related to grain 533size and magnesium content. This suggests that at least some of the carbon 534 contamination not removed by the acetic acid leach routinely applied to radiocarbon 535samples appears to be located within the Mg-ACP or at the surface of the crystallites. 536

537This has three implications:

538 1. It provides an opportunity to improve radiocarbon age estimates on tooth 539 enamel.

540 2. The effect of the acid leach on carbonate stable isotopes can be examined 541 where carbonate contamination is more effectively removed, as judged by 542 improvement in radiocarbon age.

543 3. It adds to the body of evidence on how tooth enamel alters in archaeological $544 \quad$ and palaeontological contexts.

545

5464.1 Implications for radiocarbon dating

547The offset between radiocarbon dates on enamel and the expected age of the tooth are 548compared to published dates on known-age enamel collated by Zazzo (2014) in figure 54910. When the Pleistocene teeth from Duoi U'Oi and Lang Trang were treated as 550routine radiocarbon samples, hand grinding prior to an acid leach, they fall within the 551higher end of the offsets observed for other samples. However, when mechanically 552ground, the underestimation in radiocarbon age is less than all other samples of a 553similar age. Although this improvement in age is promising, the underestimation is 554 still uncomfortably large at around $20,000{ }^{14} \mathrm{C}$ years.

555

556Although it is clear that Pleistocene enamel is unlikely to generate accurate 557radiocarbon dates using this method, it is useful to consider what effect the level of 558contamination seen in the Pleistocene teeth might have on younger samples. On 559average, the samples from Duoi U'Oi and Lang Trang have a F14C of 0.022. If we 560 assume that this is caused by modern contamination, $2.2 \%$ of the carbon in the enamel 561 must be a contaminant. In a sample of 3000 years, this level and age of contamination 562 would cause the sample to be underestimated by just 70 years, scarcely larger than the 563typical 2 sigma error range ( $\pm 50-70{ }^{14} \mathrm{C}$ years). The tooth enamel from Rach Nui, 564 which is statistically indistinguishable from charcoal from the same context, supports 565the idea that mid-late Holocene samples may not be grossly affected by contamination 566(Zazzo, 2014), if finely ground samples are acid leached prior to dating.

567

568Further work is required to assess how reproducible this age offset is. Very similar age 569 underestimates have been obtained from the three sites from two different 570 environments. However, given that at least $2 \%$ of the carbon in all mechanically 571ground samples is from a contaminant, it is highly likely that age offsets will be 572variable, and dates must be regarded as possible minimum ages. This is particularly 573important to consider where Bayesian chronological modeling is used as this will 574increase precision, exacerbating any minor systematic underestimation in age. 


\section{5}

576Improvements to the radiocarbon pretreatment protocol will depend on understanding 577where the remaining contamination is located. The mechanical grinding protocol 578employed does not completely break apart the crystallite structure, and it is possible 579that some of the Mg-ACP phase remains. Unfortunately it is not yet possible to use 580the Mg concentration to assess whether all of the Mg-ACP phase was removed during 581the leaching experiments as Mg concentration within apatite crystallite and Mg-ACP 582phase has only been measured in rodent enamel (Gordon et al., 2015), and may differ 583in the enamel of Sus scrofa.

584

585It is also likely that other diagenetic mechanisms are occurring, introducing carbon of 586a younger age. For example, it is possible that recrystallisation occurred alongside 587demineralization of areas of the tooth enamel. Further study of enamel diagenesis is 588clearly required to understand and screen for this recrystallization process, alongside 589development of new grinding protocols to more effectively break the crystallites apart 590without adding contamination (for example using SelFrag ${ }^{\mathrm{TM}}$ ).

591

5924.2 Implications for carbonate stable isotope analysis

593Tooth enamel is often washed in acetic acid prior to analysis of carbonate stable 594isotopes (Garvie-Lok et al., 2004; Lee-Thorp, 1989; Lee-Thorp and van der Merwe, 5951991). There has been some debate over whether this pretreatment can affect the final 596result through the formation of secondary minerals or recrystallization of the apatite 597crystallites (Garvie-Lok et al., 2004; Lee-Thorp and van der Merwe, 1991; Pellegrini 598and Snoeck, 2016).

599

600This study adds to the growing body of evidence that an acetic acid leach affects the 601 measured stable isotope ratios in modern enamel. For example, like this study, 602Pellegrini and Snoeck (2016) noted that the effect seems minor in terms of $\delta^{13} \mathrm{C}(<0.5$ $603 \%$ ), and is unlikely to have a large effect on the interpretation of stable isotopic data 604obtained from archaeological or palaeontological studies. We observed a slightly 605larger change in $\delta^{18} \mathrm{O}(>1 \%$ ) than Pellegrini and Snoeck (2016) which, depending on 606the research question, could have an effect on interpretation. This shift in isotopic 607value may be due to structural alteration induced by the acetic acid, but if so, these 608changes occur within the first hour of treatment and are not visible in the FTIR 609spectra. It is also possible that the isotopic signature of the carbonate within the Mg610ACP is different to that in the enamel. To investigate this possibility, further work at 611higher precision is required to assess whether trends in isotopic shift can be observed 612 between samples of different grain size.

613

614The effect of acid leaching on stable isotopes in ancient material was larger than in the 615 modern tooth. This is probably due to the removal of exogenous contamination, as the 616radiocarbon evidence demonstrates the acetic acid leach reduces contaminant levels 617 from at least $15 \%$ (hand ground) to at least $2 \%$ (micronised and leached). An acid 618 wash prior to stable isotope analysis of enamel is therefore required. 


\section{9}

620The effect $2 \%$ contamination on the stable isotopic signature of enamel depends on 621the difference between carbonate in the groundwater and carbonate in the enamel. To 622shift the isotopic signature of the enamel by more than $1 \%$, more than $10 \%$ of the 623carbonate would need to be a contaminant if the two sources of carbonate differed by $62410 \%$. This estimate agrees well with both $\delta^{13} \mathrm{C}$ and $\delta^{18} \mathrm{O}$ in the ancient samples 625 examined here, which vary by little more than 1 or $2 \%$ between untreated and 626leached micronised samples (figure 6d,e).

\section{7}

\subsection{Implications for enamel diagenesis}

629In contrast with the extensive study of bone diagenesis (Collins et al., 2002; Hedges, 6302002), relatively little work has examined how enamel degrades in the burial 631environment. However, it is clear from e.g. radiocarbon analyses (Zazzo, 2014), trace 632element analyses (Hinz and Kohn, 2010; Kohn, 2008; Sponheimer and Lee-Thorp, 6332006; Trueman and Tuross, 2002), U-series dating (Millard and Hedges, 1996; Pike et 634al., 2002), FTIR (Asscher et al., 2011) and microscopy (Hollund et al., 2014), that 635enamel is altered by chemical and possibly microbial processes.

\section{6}

637One diagenetic mechanism seems to involve the diffusion of carbonate through the 638enamel matrix, as previously observed with trace elements. The increase in age with 639decreasing grain size, and the relationship between age and $\mathrm{Mg}$ concentration 640suggests that the carbonate is not only diffusing along the larger pores at prism 641 junctions, but is diffusing between the individual crystallites.

642

$643 \mathrm{Mg}$ concentration is low in all Pleistocene enamel samples. Whilst this might be part 644of the natural variation in Mg concentration, it may also suggest that the Mg-ACP 645phase dissolves during burial. Nielsen-Marsh and Hedges (2000) have used acetic 646acid leaching to examine the diagenetic processes occurring in bone, arguing that this 647 treatment may imitate some of the processes occurring during burial. The acetic acid 648leach reduced $\mathrm{Mg}$ concentration in modern enamel, even in the hand ground samples. 649If this process does occur during burial, removal of the Mg-ACP phase may increase 650porosity, facilitating faster diffusion.

651

\section{Conclusions}

653

654Mechanically grinding tooth enamel to separate the apatite crystallites can improve 655the ability of the acetic acid wash to remove carbonate contaminants. As a result the 656accuracy of radiocarbon dates on enamel is substantially improved. However, even 657 with the grinding protocol and cleaning applied here, at least $2 \%$ of the carbonate 658 within the treated enamel was a contaminant. Teeth known to be more than 50,000 659years old were dated to c.30 kBP. Within the mid-late Holocene, this level of 660contamination would cause radiocarbon age estimates to be within c. $100{ }^{14} \mathrm{C}$ years of 661the true sample age. However, only four teeth have been examined, so variation in the 
662contamination level is unknown. Therefore all radiocarbon dates on enamel must be 663regarded as potentially inaccurate, and most likely too young.

664

665The study highlights the need for further work aiming to understand the diagenetic 666processes occurring within enamel. Only when we understand where the remaining 667contaminating carbon is located can we develop effective cleaning protocols to 668produce accurate radiocarbon dates.

669

670

\section{Acknowledgements}

672The research and R. Wood were funded by an Australian Research Council DECRA 673fellowship (DE150100070). M. Duval's research was funded by the People 674Programme (Marie Curie Actions) of the European Union's Seventh Framework 675Programme (FP7/2007-2013) under REA Grant Agreement nº PIOF-GA-2013676626474. Jaime Swift (University of Oxford) and Matthew Cupper (University of 677Melbourne) are thanked for providing the modern pig sample. Rainer Grün, Griffith 678 University, and Les Kinsley, ANU, are thanked for for their invaluable support in U679 series data acquisition and reduction processes. Stewart Fallon, ANU, is thanked for 680help with AMS. Frank Brink and Hua Chen at the Centre for Advanced Microscopy, 681ANU, are thanked for help with SEM. Penny King, ANU, is thanked for discussions 682about FTIR and carbonates and Linda McMorrow, ANU, for running the ICP-AES 683samples. Carley Crann (University of Ottawa) is thanked for suggesting SelFrag as an 684alternative method to mechanical grinding. All errors are, of course, our own.

\section{5}

\section{Table headings}

687

688Table 1: Samples used in this study. Tooth eruption and wear stages follow (Lemoine 689et al., 2014) and associated radiocarbon dates have been calibrated against IntCal13 690(Reimer et al., 2013) in OxCal v.4.2 (Ramsey, 2009).

\section{1}

692Table 2: Analytical results of the modern enamel sample BB1 after grinding by hand 693and micronising for 5, 15 and 30 minutes, and etching in acetic acid for up to 71 694hours. All measurements are on the powder remaining after treatment. Where 695replicates were made, average values are given. Standard deviations are given in the 696text. N/A refers to samples were analyses were not undertaken due to the presence of 697brushite.

698

699Table 3: U-series results on the three tooth samples from Duoi U'Oi and Lang Trang 700sites. Values were calculated by integrating the data from all the spots of a given 701domain with a dental tissue. For all domains, elemental U/Th ratios were found to 702 be above 250 , minimizing thus the impact of detrital ${ }^{232} \mathrm{Th}$ contamination on final 703age results. No age calculations (n.c.) were carried out for $U$ concentrations of $\leq 0.5$ 704ppm. All errors are 2-б. Key: EN = enamel, DE = dentine. 


\section{5}

706Table 4; Analytical results on ancient enamel samples. Micronised samples were 707milled for 30 minutes. All measurements are on the powder remaining after treatment. 708Holocene dates have been calibrated against IntCal13 (Reimer et al. 2013) in OxCal 709 v.4.2 (Ramsey 2009) and are given at 95.4\% probability.

710

\section{Figure headings}

\section{2}

713Figure 1: FESEM images of a longitudinal section of a modern Sus scrofa M3 after 714etching in acid (2M HCl, 30 seconds) and coating in Pt, demonstrating the 715 microstructure of tooth enamel. a) Enamel is the pale material to the left and dentine 716the darker material to the right. Scale bar $20 \mu \mathrm{m}$. b) Prisms (white arrows) and 717interprismatic matrix (black arrows). Scale bar $2 \mu \mathrm{m}$. c) Crystallites in prismatic and 718 interprismatic enamel. Scale bar $200 \mathrm{~nm}$.

719

720Figure 2: U-series closed system age estimates and U concentration of each ablated 721 spot in DU795. For colour, please see online version.

722

723Figure 3: U-series closed system age estimates and U concentration of each ablated 724spot from the two teeth from Lang Trang. For colour, please see online version. 725

726Figure 4: Secondary electron FESEM images of the ground modern BB1 tooth 727enamel. a-c) hand ground, scale bars $10 \mu \mathrm{m}, 1 \mu \mathrm{m}$ and $1 \mu \mathrm{m}$ respectively. $d-f$ ) 728mechanically ground for 30 minutes in a McCrone microniser, scale bars $10 \mu \mathrm{m}, 1 \mu \mathrm{m}$ 729 and $1 \mu \mathrm{m}$ respectively.

730

731Figure 5: Change in Mg concentration in tooth enamel remaining after an acid leach 732for a) modern and b) palaeontological samples of different grain size. 1 sigma error 733ranges are smaller than the data points. For colour, please see online version. 734

735Figure 6: GB-IRMS analysis of $\delta^{13} \mathrm{C}, \delta^{18} \mathrm{O}$ and \%C of a-c) modern and d-f)

736palaeontological enamel remaining after an acid leach. 1 sigma error ranges are 737indicated. For colour, please see online version.

738

739Figure 7: Radiocarbon age of enamel a) F14C and b) conventional radiocarbon age. 1 740 sigma error ranges are within the size of the datapoint. For colour, please see online 741version.

742

743Figure 8: Contamination added in the laboratory. F14C is given for mixtures of 744geological apatite and either marble (IAEA-C1, filled datapoints) and a modern oyster 745shell (open datapoints, right hand scale). Measurements on carbonate, carbonate 746mixed with hand ground apatite, carbonate mixed with micronised apatite, and 747carbonate mixed with micronised and acetic acid leached apatite are given. Errors are 
748given at $1 \sigma$ (smaller than the datapoint size for the marble-apatite mixtures), and 749F14C is presented with no laboratory background subtraction.

750

751Figure 9: Relationship between F14C and Mg concentration. For colour, please see 752online version.

753

754Figure 10; Comparison of results obtained in this study with radiocarbon dates on the 755apatite of bone, dentine and enamel collated by Zazzo (2014). Dates are given against 756the expected age. Only samples Zazzo (2014) ranked highly in terms of security of 757 known age are presented.

758

\section{References}

760

761Asscher, Y., Regev, L., Weiner, S., Boaretto, E., 2011. Atomic Disorder in Fossil 762Tooth and Bone Mineral: An FTIR Study Using the Grinding Curve Method. 763ArchéoSciences 35.

764Bacon, A.M., Demeter, F., Duringer, P., Helm, C., Bano, M., Vu, T.L., Nguyen, T.K.T., 765Antoine, P.O., Bui, T.M., Nguyen, T.M.H., Dodo, Y., Chabaux, F., Rihs, S., 2008. The 766Late Pleistocene Duoi U'Oi cave in northern Vietnam: palaeontology, 767sedimentology, taphonomy and palaeoenvironments. Quaternary Science 768Reviews 27, 1627-1654.

769Bacon, A.M., Westaway, K., Antoine, P.O., Duringer, P., Blin, A., Demeter, F., Ponche, 770J.L., Zhao, J.X., Barnes, L.M., Sayavonkhamdy, T., Nguyen, T.K.T., Vu, T.L., Patole771Edoumba, E., Shackelford, L., 2015. Late Pleistocene mammalian assemblages of 772Southeast Asia: New dating, mortality profiles and evolution of the predator-prey 773relationships in an environmental context. Palaeogeography, Palaeoclimatology, 774Palaeoecology 422, 101-127.

775Balter, V., Saliège, J.F., Bocherens, H., Person, A., 2002. Evidence of physico776chemical and isotopic modifications in archaeological bones during controlled 777acid etching. Archaeometry 44, 329-336.

778Berry, E.E., Baddiel, C.B., 1967. The infra-red spectrum of dicalcium phosphate 779dihydrate (brushite). Spectrochimica Acta Part A: Molecular Spectroscopy 23, 7802089-2097.

781Blumenthal, N.C., Betts, F., Posner, A.S., 1975. Effect of carbonate and biological 782 macromolecules on formation and properties of hydroxyapatite. Calcified Tissue 783Research 18, 81-90.

784Borggreven, J.M.P.M., Driessens, F.C.M., van Dijk, J.W.E., 1980. Diffusion through 785 bovine tooth enamel as related to the water structure in its pores. Archives of 7860ral Biology 25, 345-348.

787Borggreven, J.M.P.M., Driessens, F.C.M., van Dijk, J.W.E., 1986. Dissolution and 788 precipitation reactions in human tooth enamel under weak acid conditions. 789Archives of Oral Biology 31, 139-144.

790Borggreven, J.M.P.M., van Duk, J.W.E., Driessens, F.C.M., 1977. A quantitative 791radiochemical study of ionic and molecular transport in bovine dental enamel. 792Archives of Oral Biology 22, 467-472.

793Bottero, M.J., Yvon, J., Vadot, J., 1992. Multimethod analysis of apatites in sound 794human tooth enamel. Eur. J. Mineral. 4, 1347-1357. 
795Brown, T.A., Nelson, D.E., Vogel, J.S., Southon, J., 1988. Improved collagen 796 extraction by modified Longin method. Radiocarbon 30, 171-177.

797Brudevold, F., Srinivasan, B.N., Skobe, Z., 1977. Separation of human tooth enamel 798microstructures by density fractionation. Archives of Oral Biology 22, 593-597. 799Calo, A., Prasetyo, B., Bellwood, P., Lankton, J.W., Gratuze, B., Pryce, T.O., Reinecke, 800A., Leusch, V., Schenk, H., Wood, R., Bawono, R.A., Kompiang Gede, I.D., Citha 801Yuliati, N.L.K., Fenner, J., Reepmeyer, C., Castillo, C., Carter, A.K., 2015. Sembiran 802and Pacung on the north coast of Bali: a strategic crossroads for early trans803Asiatic exchange. Antiquity 89, 378-396.

804Ciochon, R.L., Olsen, J.W., 1991. Paleoanthropological and archaeological 805discoveries from Lang Trang caves: A new Middle Pleistocene hominid site from 806northern Vietnam. Indo-Pacific Prehistroy Association Bulletin 10, 59-73. 807Collins, M.J., Nielsen-Marsh, C.M., Hiller, J., Smith, C.I., Roberts, J.P., Prigodich, R.V., 808Wess, T.J., Csapò, J., Millard, A.R., Turner-Walker, G., 2002. The survival of organic 809matter in bone: A review. Archaeometry 44, 383-394.

810Cucchi, T., Fujita, M., Dobney, K., 2009. New insights into pig taxonomy, 811domestication and human dispersal in Island South East Asia: Molar shape 812analysis of Sus remains from Niah Caves, Sarawak. International Journal of 8130steoarchaeology 19, 508-530.

814Cui, F.Z., Ge, J., 2007. New observations of the hierarchical structure of human 815enamel, from nanoscale to microscale. Journal of Tissue Engineering and 816Regenerative Medicine 1, 185-191.

817Driessens, F.C., 1982. Mineral aspects of dentistry. Monographs in oral science 10, 8181-215.

819Driessens, F.C.M., Verbeeck, R.M.H., 1982. The probable phase composition of the 820mineral in sound enamel and dentine. Bulletin des Societes Chimiques Belges 97, 821573-596.

822Driessens, F.C.M., Verbeeck, R.M.H., 1985. Dolomite as a possible magnesium823containing phase in human tooth enamel. Calcified Tissue International 37, 376824380 .

825Eggins, S., Grün, R., Pike, A.W.G., Shelley, M., Taylor, L., 2003. 238U, 232Th 826profiling and U-series isotope analysis of fossil teeth by laser ablation-ICPMS. 827Quaternary Science Reviews 22, 1373-1382.

828Eggins, S.M., Grün, R., McCulloch, M.T., Pike, A.W.G., Chappell, J., Kinsley, L., 829Mortimer, G., Shelley, M., Murray-Wallace, C.V., Spötl, C., Taylor, L., 2005. In situ U830series dating by laser-ablation multi-collector ICPMS: New prospects for 831Quaternary geochronology. Quaternary Science Reviews 24, 2523-2538. 832Elliott, J.C., 1994. Structure and chemistry of the apatites and other calcium 833orthophosphates. Elsevier, Amsertdam.

834Elliott, J.C., 2002. Calcium phosphate biominerals, Reviews in Mineralogy and 835Geochemistry.

836Evin, A., Dobney, K., Schafberg, R., Owen, J., Strand Vidarsdottir, U., Larson, G., 837Cucchi, T., 2015. Phenotype and animal domestication: A study of dental variation 838between domestic, wild, captive, hybrid and insular Sus scrofa. BMC Evolutionary 839Biology 15.

840Fallon, S.J., Fifield, L.K., Chappell, J.M., 2010. The next chapter in radiocarbon 841dating at the Australian National University: Status report on the single stage 842AMS. Nuclear Instruments and Methods in Physics Research, Section B: Beam 843Interactions with Materials and Atoms 268, 898-901. 
844Fleet, M.E., 2009. Infrared spectra of carbonate apatites: v2-Region bands. 845Biomaterials 30, 1473-1481.

846Frazier, P.G., 1970. II. An electron microscopic study of the effect of grinding. 847Calcified Tissue International 5, 277-287.

848Garvie-Lok, S.J., Varney, T.L., Katzenberg, M.A., 2004. Preparation of bone 849carbonate for stable isotope analysis: The effects of treatment time and acid 850concentration. Journal of Archaeological Science 31, 763-776.

$851 G o r d o n$, L.M., Cohen, M.J., MacRenaris, K.W., Pasteris, J.D., Seda, T., Joester, D., 8522015. Amorphous intergranular phases control the properties of rodent tooth 853enamel. Science 347, 746-750.

854Gordon, L.M., Joester, D., 2015. Mapping residual organics and carbonate at grain 855 boundaries and the amorphous interphase in mouse incisor enamel. Frontiers in 856Physiology 6.

857Grøn, P., Spinelli, M., Trautz, O., Brudevold, F., 1963. The effect of carbonate on the 858solubility of hydroxylapatite. Archives of Oral Biology 8, 251-263.

859Grün, R., Abeyratne, M., Head, J., Tuniz, C., Hedges, R.E.M., 1997. AMS 14C analysis 860of teeth from archaeological sites showing anomalous ESR dating results.

861Quaternary Science Reviews 16, 437-444.

862Grün, R., Eggins, S., Kinsley, L., Moseley, H., Sambridge, M., 2014. Laser ablation U863series analysis of fossil bones and teeth. Palaeogeography, Palaeoclimatology, 864Palaeoecology 416, 150-167.

865Haas, H., Banewicz, J., 1980. Radiocarbon dating of bone apatite using thermal 866release of $\mathrm{CO}<\mathrm{inf}>2</$ inf $>$. Radiocarbon 22, 537-544.

867Hallsworth, A.S., Robinson, C., Weatherell, J.A., 1972. Mineral and magnesium 868distribution within the approximal carious lesion of dental enamel. Caries 869Research 6, 156-168.

870Haynes, V., 1968. Radiocarbon: Analysis of inorganic carbon of fossil bone and 871enamel. Science 161, 687-688.

872 Hedges, R., Lee-Thorpe, J.A., Tuross, N.C., 1995. Is tooth enamel carbonate a 873suitable material for radiocarbon dating. Radiocarbon 37, 285-290.

874Hedges, R.E.M., 2002. Bone diagenesis: An overview of processes. Archaeometry 87544, 319-328.

876Hinz, E.A., Kohn, M.J., 2010. The effect of tissue structure and soil chemistry on

877trace element uptake in fossils. Geochimica et Cosmochimica Acta 74, 3213-3231. 878Hollund, H.I., Jans, M.M.E., Kars, H., 2014. How are teeth better than bone? An 879investigation of dental tissue diagenesis and state of preservation at a 880histological scale (with photo catalogue). Internet Archaeology.

881Hunt, G.R., Vincent, R.K., 1968. The behaviour of spectral features in the infrared 882 emission from particulare surfaces of various grain sizes. Journal of Geophysical 883Research 73, 6039-6046.

884Koenigswald, W.V., Sander, P.M., 1997. Glossary of terms used for enamel 885 microstructures, in: Koenigswald, W.V., Sander, P.M. (Eds.), Tooth enamel 886microsctructure. A.A. Balkema, Rotterdam, pp. 267-280.

887Kohn, M.J., 2008. Models of diffusion-limited uptake of trace elements in fossils 888and rates of fossilization. Geochimica et Cosmochimica Acta 72, 3758-3770. 889Larsen, M.J., Jensen, S.J., 1989. Stability and mutual conversion of enamel apatite 890 and brushite at $20^{\circ} \mathrm{C}$ as a function of $\mathrm{pH}$ of the aqueous phase. Archives of Oral 891Biology 34, 963-968. 
892Lee-Thorp, J., 2002. Two decades of progress towards understanding fossilization 893processes and isotopic signals in calcified tissue minerals. Archaeometry 44, 435894446.

895Lee-Thorp, J., Manning, L., Sponheimer, M., 1997. Problems and prospects for 896 carbon isotope analysis of very small samples of fossil tooth enamel. Bulletin de 897la Societe Geologique de France 168, 767-773.

898Lee-Thorp, J.A., 1989. Stable carbon isotopes in deep time: The diets of fossil 899fauna and hominids. Stable Carbon Isotopes in Deep Time: The Diets of Fossil 900Fauna and Hominids.

901Lee-Thorp, J.A., van der Merwe, N.J., 1991. Aspects of the chemistry of modern 902and fossil biological apatites. Journal of Archaeological Science 18, 343-354. 903LeGeros, R.Z., Tung, M.S., 1983. Chemical stability of carbonate- and fluoride904containing apatites. Caries Research 17, 419-429.

905Lemoine, X., Zeder, M.A., Bishop, K.J., Rufolo, S.J., 2014. A new system for 906computing dentition-based age profiles in Sus scrofa. Journal of Archaeological 907Science 47, 179-193.

908Lindén, L.A., 1968. Microscopic observations of fluid flow through enamel in 909vitro. Odontologisk revy 19, 349-365.

910Long, V.T., de Vos, J., Ciochon, R.L., 1996. The fossil mammal fauna of the Lang 911Trang Caves, Vietnam, compared with Southeast Asian fossil and recent mammal 912faunas: the geographical implications. Indo-Pacific Prehistroy Association 913Bulletin 14, 101-109.

914Longin, R., 1971. New method of collagen extraction for radiocarbon dating. 915Nature 230, 241-242.

916Marom, A., McCullagh, J.S.O., Higham, T.F.G., Sinitsyn, A.A., Hedges, R.E.M., 2012. 917Single amino acid radiocarbon dating of Upper Paleolithic modern humans. 918Proceedings of the National Academy of Sciences of the United States of America 919109, 6878-6881.

920McCullagh, J.S.O., Marom, A., Hedges, R.E.M., 2010. Radiocarbon dating of 921individual amino acids from archaeological bone collagen. Radiocarbon 52, 620922634.

923Millard, A.R., Hedges, R.E.M., 1996. A diffusion-adsorption model of uranium 924uptake by archaeological bone. Geochimica et Cosmochimica Acta 60, 2139-2152. 925Nielsen-Marsh, C.M., Hedges, R.E.M., 2000. Patterns of diagenesis in bone II: 926Effects of acetic acid treatment and the removal of diagenetic CO3 2. Journal of 927Archaeological Science 27, 1151-1159.

9280xenham, M.F., Piper, P.J., Bellwood, P., Bui, C.H., Nguyen, K.T.K., Nguyen, Q.M., 929Campos, F., Castillo, C., Wood, R., Sarjeant, C., Amano, N., Willis, A., Ceron, J., 2015. 930Emergence and Diversification of the Neolithic in Southern Vietnam: Insights 931From Coastal Rach Nui. Journal of Island and Coastal Archaeology 10, 309-338. 932Pellegrini, M., Snoeck, C., 2016. Comparing bioapatite carbonate pre-treatments 933for isotopic measurements: Part 2 - Impact on carbon and oxygen isotope 934compositions. Chemical Geology 420, 88-96.

935Petrov, I., Šoptrajanov, B., Fuson, N., Lawson, J.R., 1967. Infra-red investigation of 936dicalcium phosphates. Spectrochimica Acta Part A: Molecular Spectroscopy 23, 9372637-2646.

938Pike, A.W.G., Hedges, R.E.M., Van Calsteren, P., 2002. U- series dating of bone using 939the diffusion- adsorption model. Geochimica et Cosmochimica Acta 66, 42739404286. 
941Ramsey, C.B., 2009. Bayesian analysis of radiocarbon dates. Radiocarbon 51, 337942360.

943Ramsey, C.B., Higham, T., Bowles, A., Hedges, R., 2004. Improvements to the 944pretreatment of bone at Oxford. Radiocarbon 46, 155-163.

945Reimer, P.J., Bard, E., Bayliss, A., Beck, J.W., Blackwell, P.G., Bronk Ramsey, C., Buck, 946C.E., Cheng, H., Edwards, R.L., Friedrich, M., Grootes, P.M., Guilderson, T.P., 947Haflidason, H., Hajdas, I., Hatté, C., Heaton, T.J., Hoffmann, D.L., Hogg, A.G., 948Hughen, K.A., Kaiser, K.F., Kromer, B., Manning, S.W., Niu, M., Reimer, R.W., 949Richards, D.A., Scott, E.M., Southon, J.R., Staff, R.A., Turney, C.S.M., van der Plicht, 950J., 2013. IntCal13 and Marine13 radiocarbon age calibration curves 0-50,000 951years cal BP. Radiocarbon 55, 1869-1887.

952Reimer, P.J., Brown, T.A., Reimer, R.W., 2004. Discussion: Reporting and calibration 953of post-bomb 14C data. Radiocarbon 46, 1299-1304.

954Shellis, R.P., Dibdin, G.H., 2000. Enamel microporosity and its functional 955implications, in: Ferguson, M.W.J., Smith, M.M., Teaford, M.F. (Eds.), Development, 956Function and Evolution of Teeth. Cambridge University Press, West Nyack, New 957York.

958Sillen, A., LeGeros, R., 1991. Solubility profiles of synthetic apatites and of 959modern and fossil bones. Journal of Archaeological Science 18, 385-397. 960Sponheimer, M., Lee-Thorp, J.A., 2006. Enamel diagenesis at South African 961Australopith sites: Implications for paleoecological reconstruction with trace 962elements. Geochimica et Cosmochimica Acta 70, 1644-1654.

963Stafford Jr, T.W., Brendel, K., Duhamel, R.C., 1988. Radiocarbon, 13C and 15N 964 analysis of fossil bone: Removal of humates with XAD-2 resin. Geochimica et 965Cosmochimica Acta 52, 2257-2267.

966Storm, P., Wood, R., Stringer, C., Bartsiokas, A., De Vos, J., Aubert, M., Kinsley, L., 967Grün, R., 2013. U-series and radiocarbon analyses of human and faunal remains 968from Wajak, Indonesia. Journal of Human Evolution 64, 356-365.

969Stuiver, M., Polach, H.A., 1977. Reporting of 14C Data. Radiocarbon 19, 355-363. 970Surovell, T.A., 2000. Radiocarbon Dating of Bone Apatite by Step Heating.

971Geoarchaeology - An International Journal 15, 591-608.

972Tisnérat-Laborde, N., Valladas, H., Kaltnecker, E., Arnold, M., 2003. AMS

973radiocarbon dating of bones at LSCE. Radiocarbon 45, 409-419.

974Trueman, C.N., Tuross, N., 2002. Trace elements in recent and fossil bone apatite, 975Reviews in Mineralogy and Geochemistry.

976Van Strydonck, M., Boudin, M., De Mulder, G., 2009. 14C dating of cremated bones: 977The issue of sample contamination. Radiocarbon 51, 553-568.

978Wood, R.E., Barroso-Ruíz, C., Caparrós, M., Jordá Pardo, J.F., Santos, B.G., Higham, 979T.F.G., 2013. Radiocarbon dating casts doubt on the late chronology of the Middle 980to Upper Palaeolithic transition in southern Iberia. Proceedings of the National 981Academy of Sciences of the United States of America 110, 2781-2786.

982Yi, H., Balan, E., Gervais, C., Ségalen, L., Roche, D., Person, A., Fayon, F., Morin, G., 983Babonneau, F., 2014. Probing atomic scale transformation of fossil dental enamel 984using Fourier transform infrared and nuclear magnetic resonance spectroscopy: 985A case study from the Tugen Hills (Rift Gregory, Kenya). Acta Biomaterialia 10, 9863952-3958.

987Zahradnik, R.T., Moreno, E.C., 1975. Structural features of human dental enamel 988as revealed by isothermal water vapour sorption. Archives of Oral Biology 20, 989317-325. 
990Zazzo, A., 2014. Bone and enamel carbonate diagenesis: A radiocarbon 991prospective. Palaeogeography, Palaeoclimatology, Palaeoecology 416, 168-178. 992Zazzo, A., Lebon, M., Chiotti, L., Comby, C., Delqué-Količ, E., Nespoulet, R., Reich, I., 9932013. Can we use calcined bones for radiocarbon dating the Paleolithic? 994Radiocarbon 55, 1409-1421.

995Zazzo, A., Munoz, O., Saliège, J.F., 2014. Diet and mobility in a late neolithic 996population of coastal oman inferred from radiocarbon dating and stable isotope 997analysis. American Journal of Physical Anthropology 153, 353-364.

998Zazzo, A., Saliège, J.F., 2011. Radiocarbon dating of biological apatites: A review. 999Palaeogeography, Palaeoclimatology, Palaeoecology 310, 52-61.

1000 
1001Table 1: Samples used in this study. Tooth eruption and wear stages follow (Lemoine et al., 2014) and associated radiocarbon dates have been 1002calibrated against IntCal13 (Reimer et al., 2013) in OxCal v.4.2 (Ramsey, 2009) and are given at 95.4\% probability.

1003

\begin{tabular}{|c|c|c|c|c|c|}
\hline Sample ID & BB1 & LT1 & LT4 & DU795 & ISO6 \\
\hline Location & $\begin{array}{l}\text { Farm, Byron } \\
\text { Bay, NSW, } \\
\text { Australia } \\
\end{array}$ & Lang Trang, Vietnam & Lang Trang, Vietnam & Duoi U'Oi, Vietnam & Rach Nui, Vietnam \\
\hline Context & Surface & Cave 2, Breccia 5 & Cave 2, Breccia 5 & Breccia & 12RN H1L34/1 C1 1034/1 \\
\hline Expected age & Modern & $>50 \mathrm{ka}$ & $>50 \mathrm{ka}$ & $>50 \mathrm{ka}$ & $\begin{array}{l}\text { 3550-3360 cal BP (SANU-30823, } 3200 \\
\pm 35 \text { BP, Oxenham, et al. (2015)) }\end{array}$ \\
\hline Tooth & $\begin{array}{l}\text { M3, lower } \\
\text { right }\end{array}$ & $\begin{array}{l}\text { M3, upper right } \\
\text { anterior cusp }\end{array}$ & M3, lower left & M3, lower left & M2 \\
\hline Wear stage & $5-6$ & $4-7$ & $4-8$ & $9-10$ & $4-5$ \\
\hline
\end{tabular}


1005Table 2: Analytical results on the modern enamel sample BB1 after grinding by hand 1006and micronizing for 5, 15 and 30 minutes, and etching in acetic acid for up to 71 1007hours. All measurements are on the powder remaining after treatment.

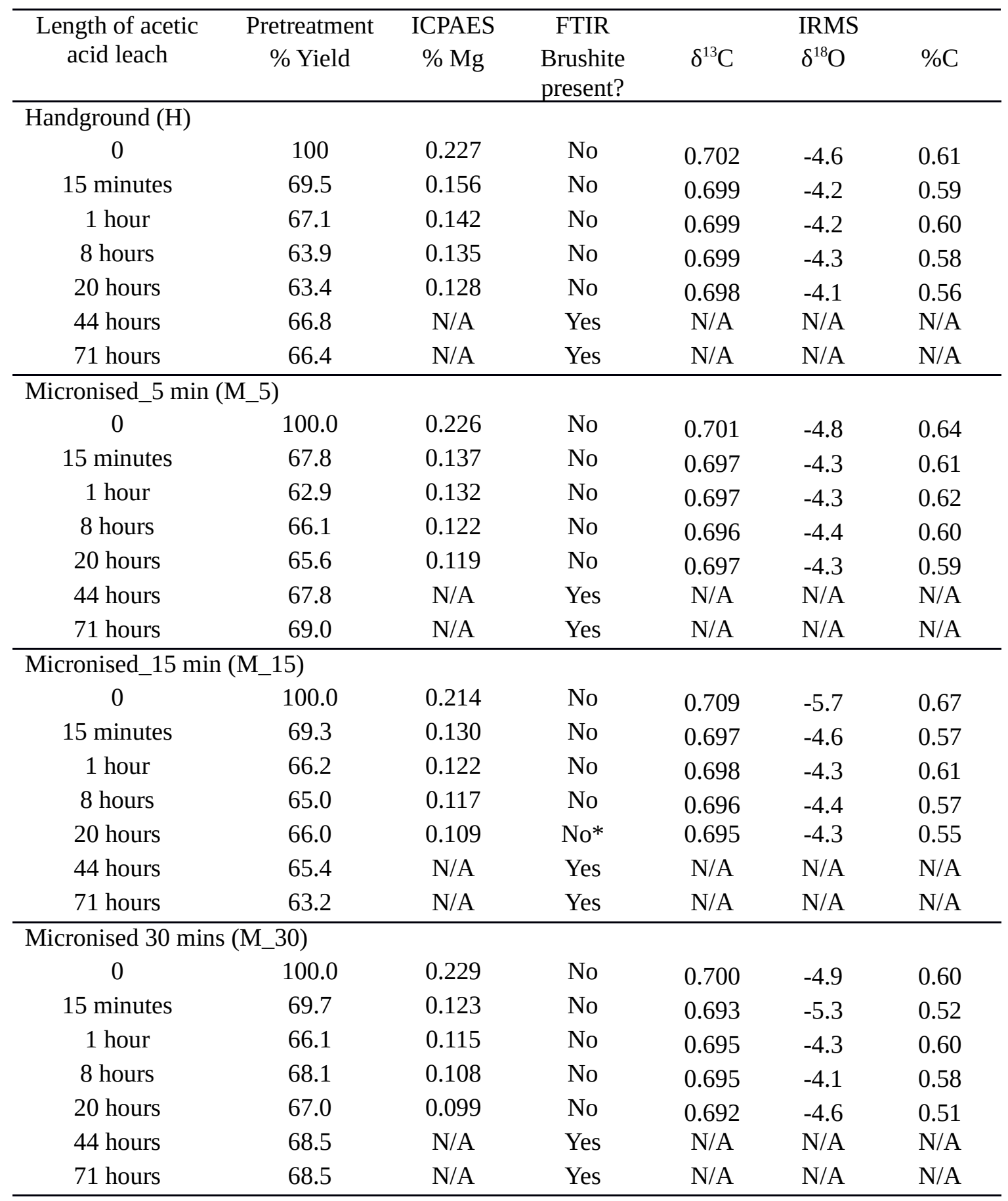

1009* A small shoulder may be present at around $525 \mathrm{~cm}^{-1}$, suggesting small amounts of 1010brushite may be present. 
1011Table 3: U-series results on the three tooth samples from Duoi U'Oi and Lang Trang 1012sites. No age calculations (n.c.) were carried out for $U$ concentrations of $\leq 0.5 \mathrm{ppm}$. 1013All errors are 2- $\sigma$. Key: $\mathrm{EN}=$ enamel, $\mathrm{DE}=$ dentine.

1014

\begin{tabular}{llllllllll}
\hline $\begin{array}{l}\text { Sampl } \\
\text { e }\end{array}$ & Tissue & U(ppm) & Error & R08 & R08-error & R48 & R48-error & CS age (ka) $\begin{array}{l}\text { CS age error } \\
\text { (ka) }\end{array}$ \\
\hline DU795 & EN1 & 3.81 & 2.23 & 0.781 & 0.005 & 1.218 & 0.005 & 106.8 & 1.45 \\
& DE1 & 82.97 & 1.02 & 0.805 & 0.003 & 1.220 & 0.002 & 112.0 & 0.79 \\
& EN2 & 4.38 & 4.12 & 0.806 & 0.012 & 1.287 & 0.007 & 101.8 & 2.66 \\
& EN3 & 1.09 & 0.33 & 0.803 & 0.012 & 1.262 & 0.009 & 104.8 & 2.82 \\
\hline LT1 & EN1 & 0.77 & 0.44 & 1.803 & 0.637 & 1.818 & 0.064 & 235.3 & 234.07 \\
& DE1 & 7.16 & 0.32 & 2.084 & 0.010 & 1.790 & 0.006 & 498.1 & 32.97 \\
& EN2 & 1.21 & 0.32 & 1.758 & 0.013 & 1.835 & 0.008 & 214.1 & 4.81 \\
& DE2 & 5.97 & 0.29 & 1.997 & 0.011 & 1.795 & 0.006 & 360.8 & 12.47 \\
\hline LT4 & EN1 & 0.27 & 0.19 & 0.728 & 0.024 & 1.343 & 0.016 & n.c. & \\
& DE1 & 1.93 & 0.58 & 0.950 & 0.012 & 1.372 & 0.008 & 118.9 & 2.95 \\
& EN2 & 0.06 & 0.03 & 1.049 & 0.194 & 1.277 & 0.087 & n.c. & \\
& EN3 & 0.02 & 0.00 & 1.511 & 0.207 & 1.248 & 0.115 & n.c. & \\
& DE3 & 3.94 & 0.63 & 0.909 & 0.010 & 1.333 & 0.007 & 116.5 & 2.53 \\
\hline
\end{tabular}


1015Table 4: Analytical results on ancient enamel samples. Micronised samples were milled for 30 minutes. All measurements are on the powder 1016remaining after treatment. Holocene dates have been calibrated against IntCal13 (Reimer et al. 2013) in OxCal v.4.2 (Ramsey 2009) and are 1017 given at $95.4 \%$ probability.

\begin{tabular}{|c|c|c|c|c|c|c|c|c|c|c|c|c|c|c|}
\hline \multicolumn{2}{|c|}{ Sample } & \multirow{3}{*}{$\begin{array}{l}\text { Pre- } \\
\text { treatment } \\
\% \text { Yield }\end{array}$} & \multicolumn{7}{|c|}{ AMS } & \multirow{2}{*}{$\begin{array}{c}\text { ICPAES } \\
\% \mathrm{Mg}\end{array}$} & \multirow{2}{*}{$\begin{array}{c}\text { FTIR } \\
\text { Brushite } \\
\text { present? }\end{array}$} & \multicolumn{3}{|c|}{ IRMS } \\
\hline $\begin{array}{l}\text { Grinding } \\
\text { method }\end{array}$ & $\begin{array}{l}\text { Time in } \\
\text { acid (hr) }\end{array}$ & & SANU- & F14C & $\begin{array}{l}\text { F14C } \\
\text { error }\end{array}$ & $\begin{array}{l}\text { Date } \\
\text { (BP) }\end{array}$ & $\begin{array}{l}\text { Date } \\
\text { error }\end{array}$ & $\begin{array}{l}\text { Cal } \\
\text { age ( }\end{array}$ & $\begin{array}{l}\text { ted } \\
\text { BP) }\end{array}$ & & & $\delta^{13} \mathrm{C}$ & $\delta^{18} \mathrm{O}$ & $\% \mathrm{C}$ \\
\hline & & & & & & & & from & to & & & & & \\
\hline
\end{tabular}

\begin{tabular}{|c|c|c|c|c|c|c|c|c|c|c|c|c|c|c|}
\hline \multirow{2}{*}{\multicolumn{15}{|c|}{ LT1 }} \\
\hline & & & & & & & & & & & & & & \\
\hline Hand & 0 & 100 & 44706 & 0.17123 & 0.00108 & 14176 & 56 & & & 0.136 & No & -12.962 & -7.3 & 0.77 \\
\hline Hand & 20 & 80.5 & 44716 & 0.07939 & 0.00086 & 20351 & 92 & & & 0.129 & No & -13.614 & -6.9 & 0.72 \\
\hline Micronised & 0 & 100 & 44711 & 0.20265 & 0.00117 & 12823 & 51 & & & 0.275 & No & -13.126 & -9.1 & 0.83 \\
\hline Micronised & 20 & 72.9 & 44719 & 0.02788 & 0.00078 & 28756 & 230 & & & 0.112 & No & -13.876 & -6.6 & 0.65 \\
\hline \multicolumn{15}{|l|}{ LT4 } \\
\hline Hand & 0 & 100 & 44707 & 0.14092 & 0.00115 & 15741 & 71 & & & 0.132 & No & -13.514 & -8.5 & 0.73 \\
\hline Hand & 20 & 75.3 & 44717 & 0.08022 & 0.00087 & 20267 & 92 & & & 0.126 & No & -13.988 & -8.5 & 0.77 \\
\hline Micronised & 0 & 100 & 44712 & 0.18924 & 0.00110 & 13373 & 52 & & & 0.138 & No & -13.657 & -9.9 & 0.78 \\
\hline Micronised & 20 & 69.2 & 44720 & 0.01796 & 0.00077 & 32288 & 349 & & & 0.097 & No* & -14.378 & -7.6 & 0.58 \\
\hline \multicolumn{15}{|l|}{ DU795 } \\
\hline Hand & 0 & 100 & 44709 & 0.12620 & 0.00099 & 16627 & 68 & & & 0.157 & No & -12.172 & -8.2 & 0.74 \\
\hline Hand & 20 & 78.7 & 44718 & 0.07065 & 0.00093 & 21288 & 111 & & & 0.135 & No & -13.035 & -8.1 & 0.74 \\
\hline Micronised & 0 & 100 & 44713 & 0.17632 & 0.00120 & 13941 & 60 & & & 0.127 & No & -12.275 & -9.7 & 0.80 \\
\hline Micronised & 20 & 68.3 & 44721 & 0.02141 & 0.00078 & 30878 & 298 & & & 0.098 & No & -13.636 & -7.5 & 0.61 \\
\hline \multicolumn{15}{|l|}{ ISO-6 } \\
\hline Hand & 0 & 100 & 44710 & 0.71781 & 0.00216 & 2663 & 29 & 2844 & 2745 & 0.246 & No & -11.760 & -5.9 & 0.77 \\
\hline Micronised & 0 & 100 & 44714 & 0.73180 & 0.00225 & 2508 & 30 & 2738 & 2489 & 0.148 & No & -11.358 & -6.5 & 0.80 \\
\hline Micronised & 20 & 70.1 & 44723 & 0.67728 & 0.00204 & 3130 & 29 & 3443 & 3250 & 0.130 & No & -11.793 & -4.4 & 0.63 \\
\hline
\end{tabular}

$1018^{*}$ A small shoulder may be present at around $525 \mathrm{~cm}^{-1}$, suggesting small amounts of brushite may be present. 


\section{a}
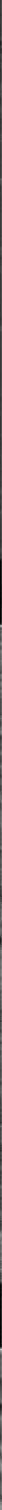

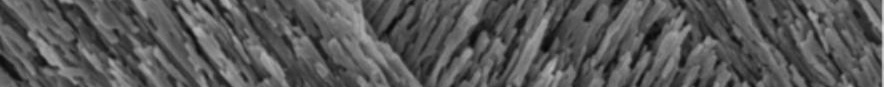
N.W. N.

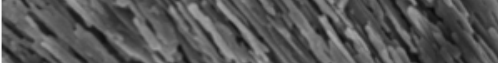

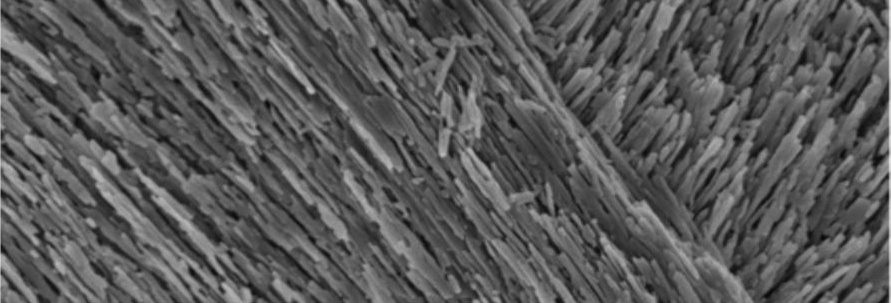




\section{DU795}

EN1

\section{DU795}

EN2

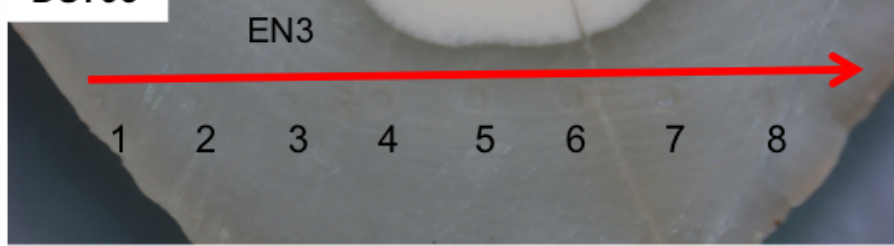

$\begin{array}{lllllllllllllll}1 & 2 & 3 & 4 & 5 & 6 & 7 & 8 & 9 & 10 & 11 & 12 & 13 & 14 & 15\end{array}$
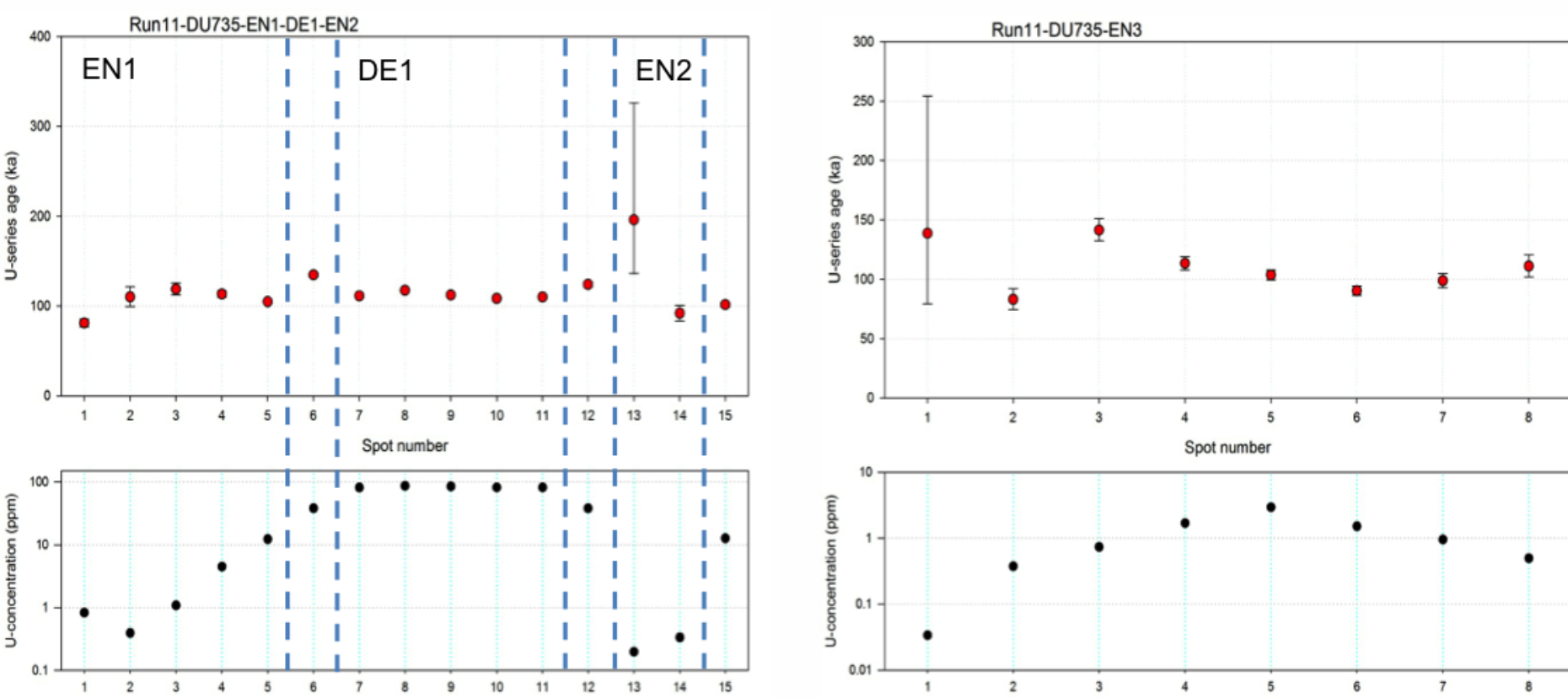

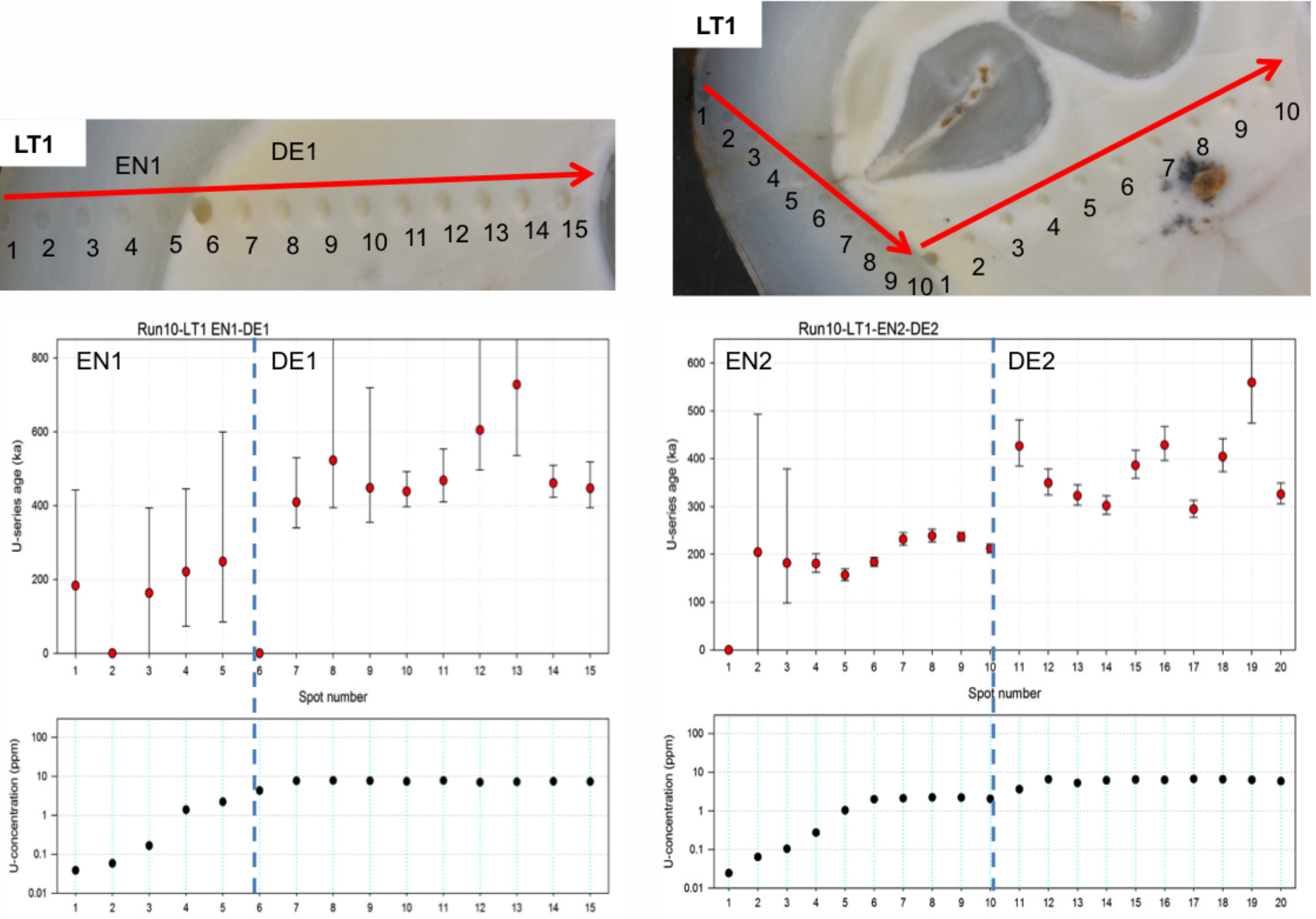

\section{LT4}

EN1

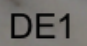

EN2

$\begin{array}{lllllllllllll}1 & 2 & 3 & 4 & 5 & 6 & 7 & 8 & 9 & 10 & 11 & 12 & 13\end{array}$
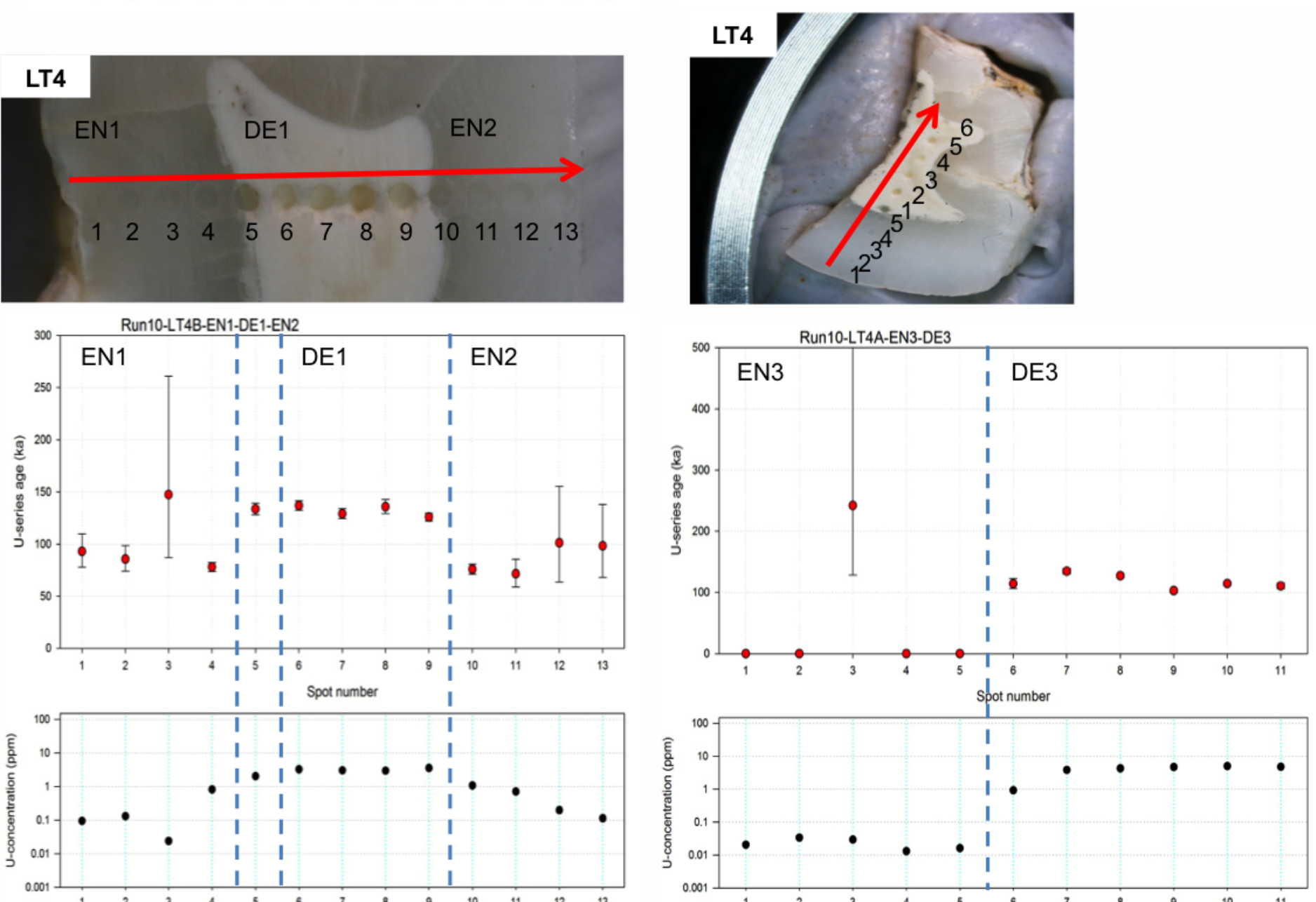


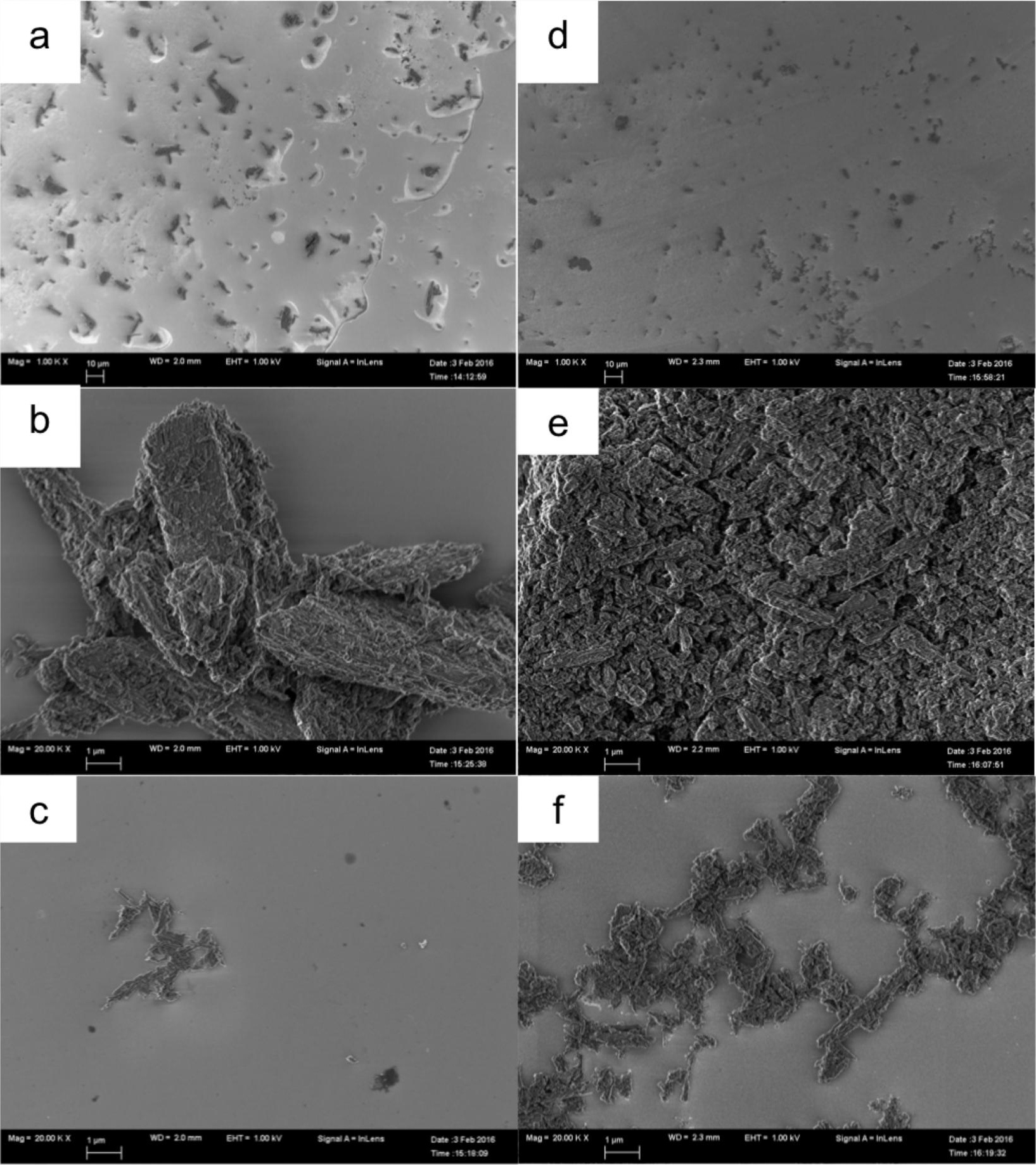




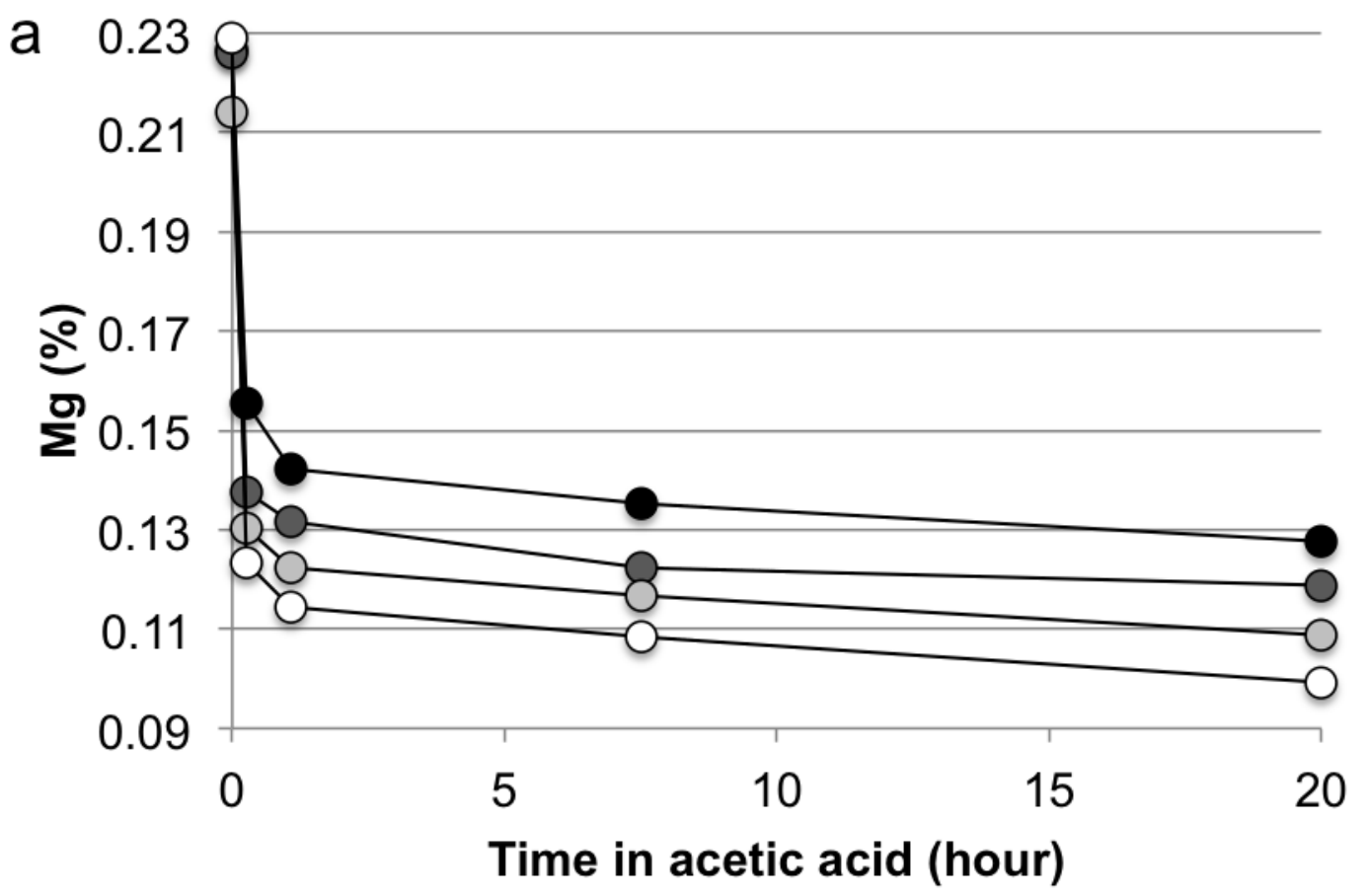

- Hand ground

-O-M_5

-O-M_15

-O-M_30

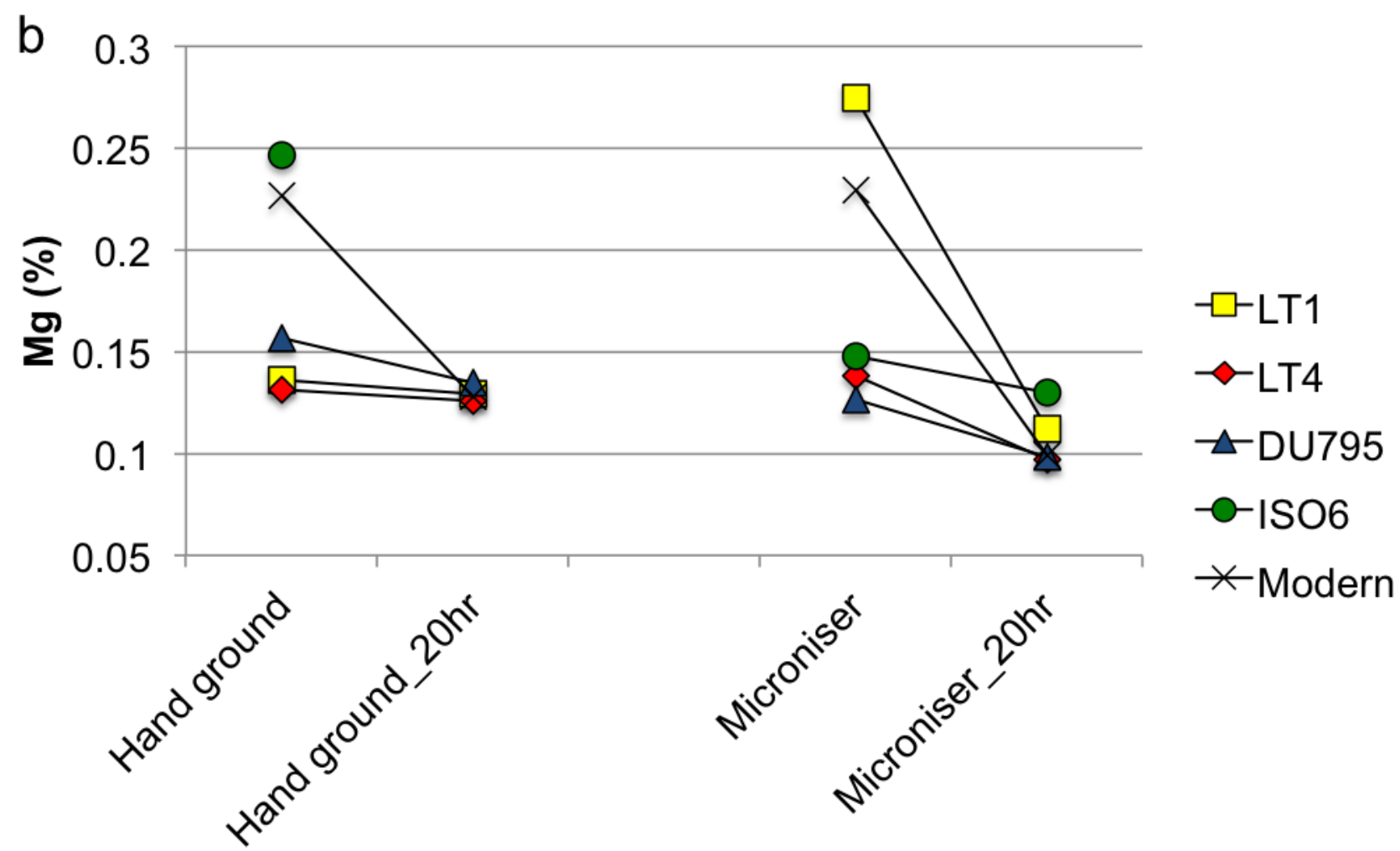



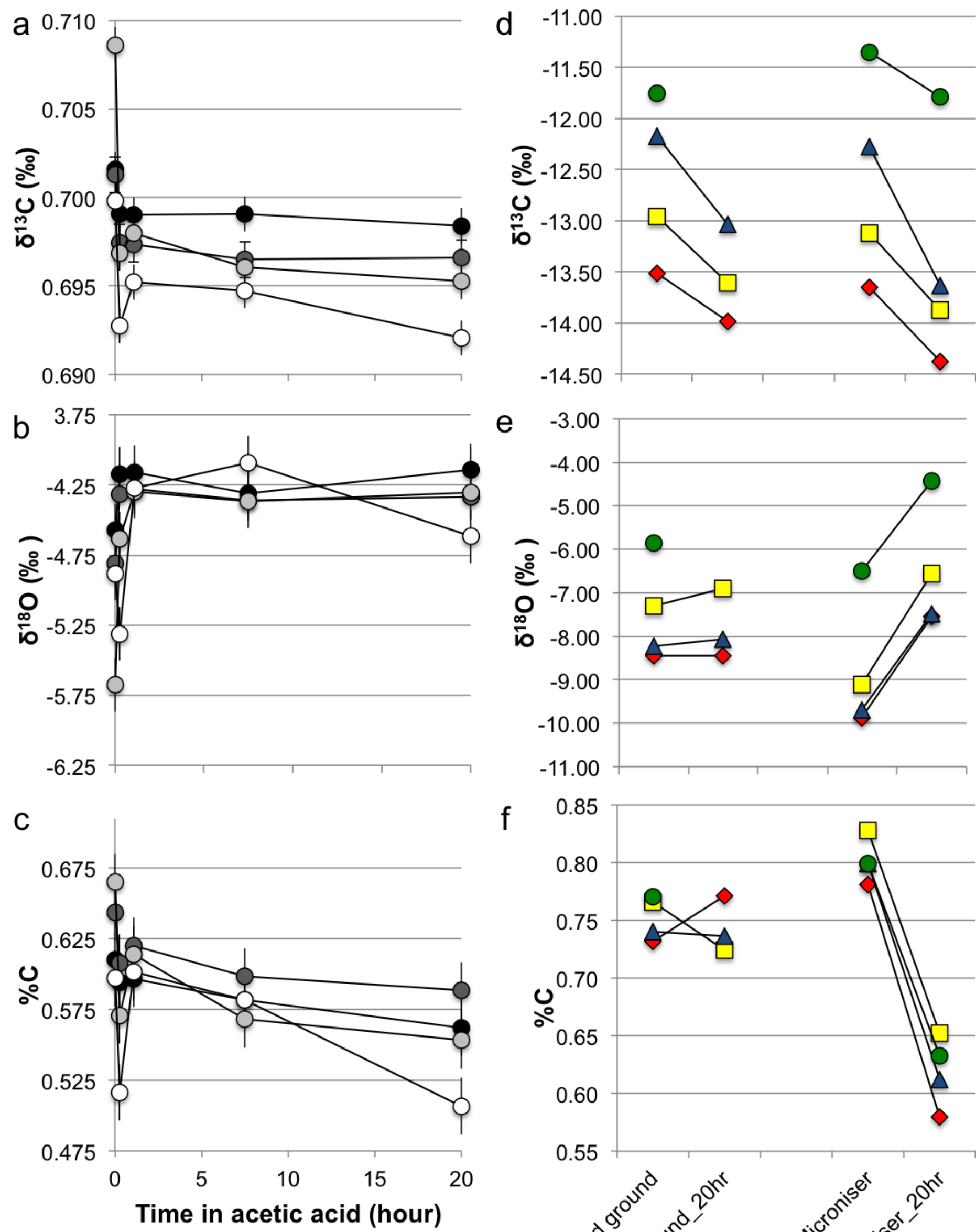

f $\quad 0.85$
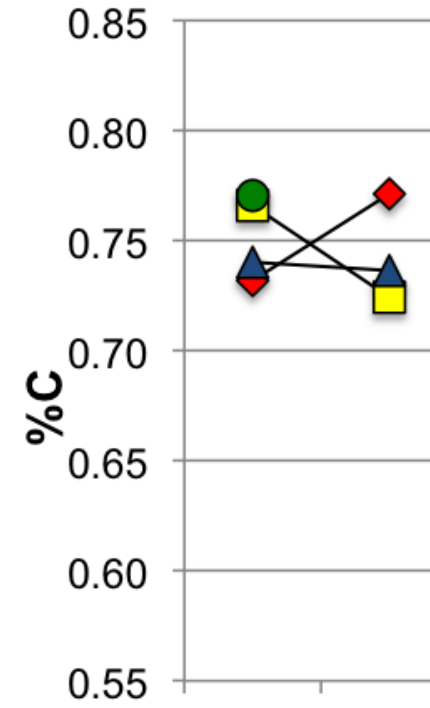

Hand ground $\quad-O-M$

$$
\text { M_15 -O-M_30 }
$$

Grinding conditions_acid leach $\neg$-LT1 $\prec$ LT4 $\triangle$ DU795 -ISO6 

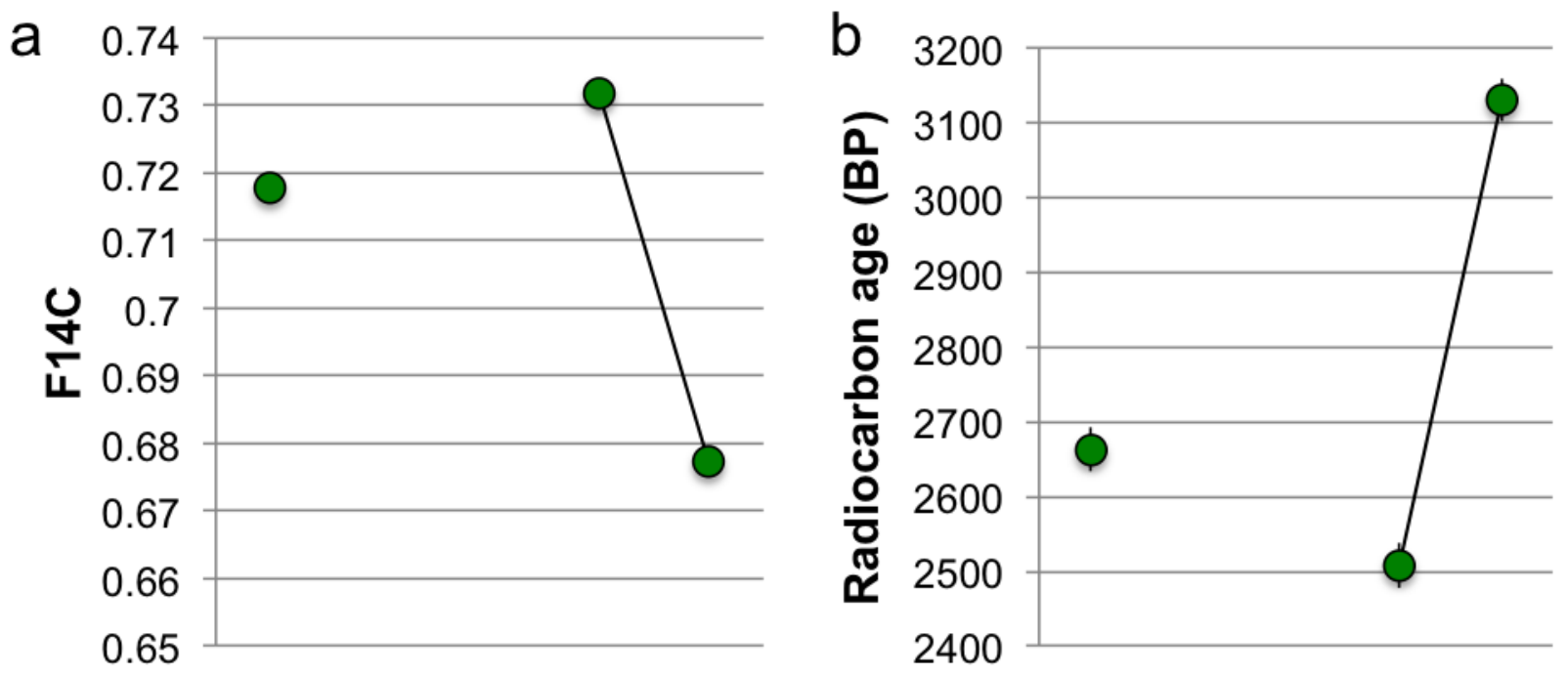

-O-ISO6
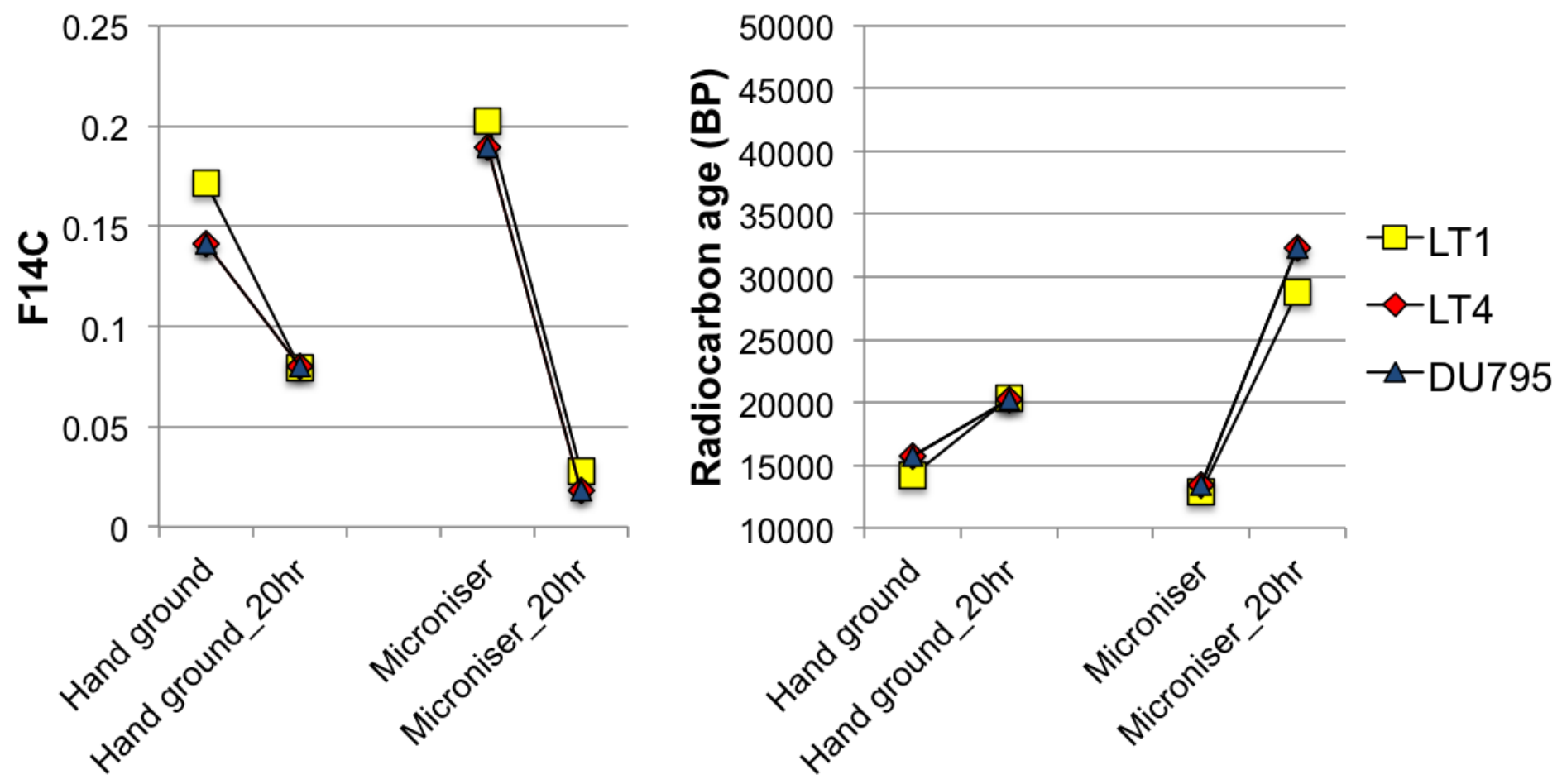

Grinding conditions_acid leach 


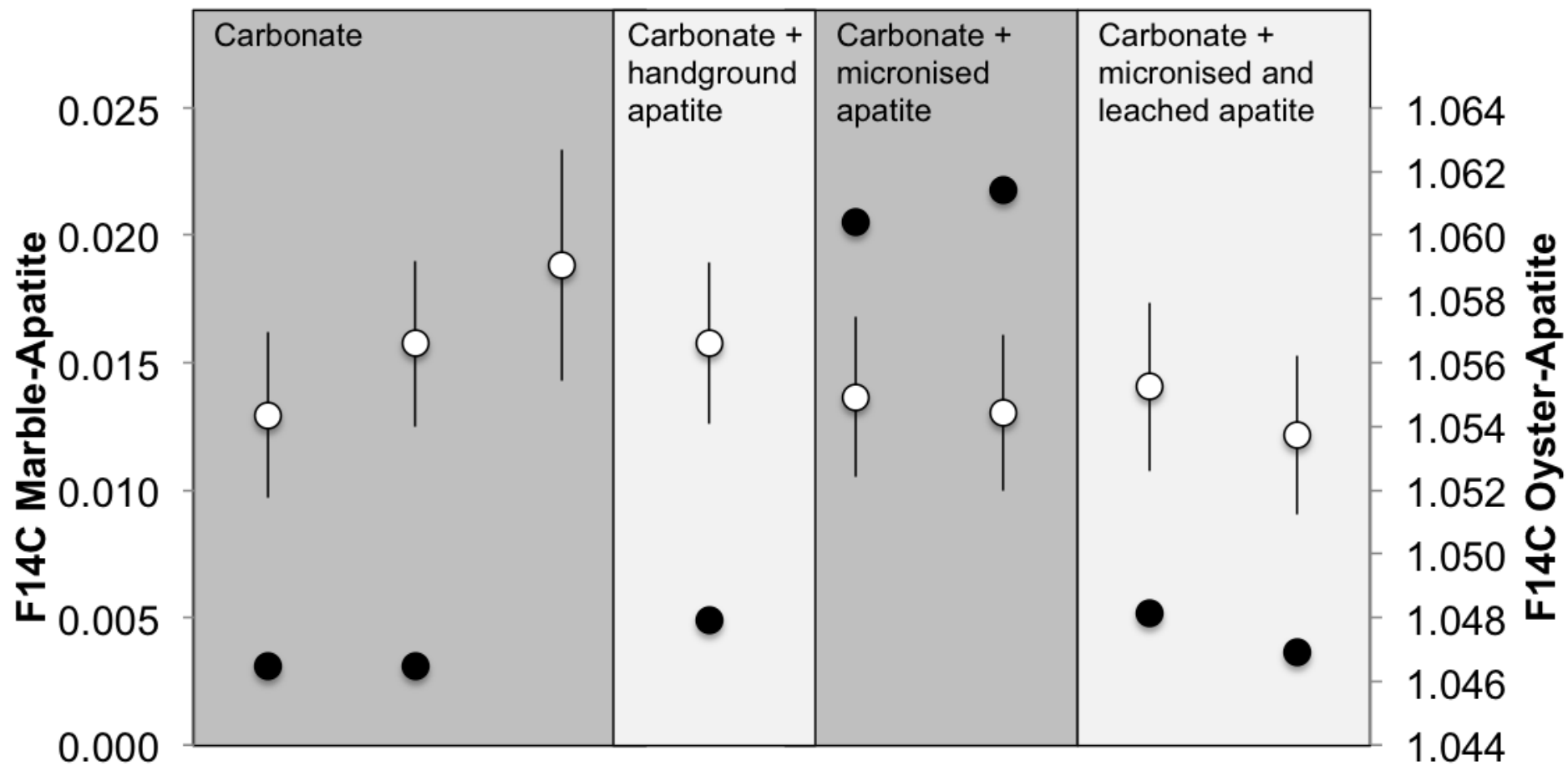

- Marble - apatite mixture OOyster-apatite mixture 


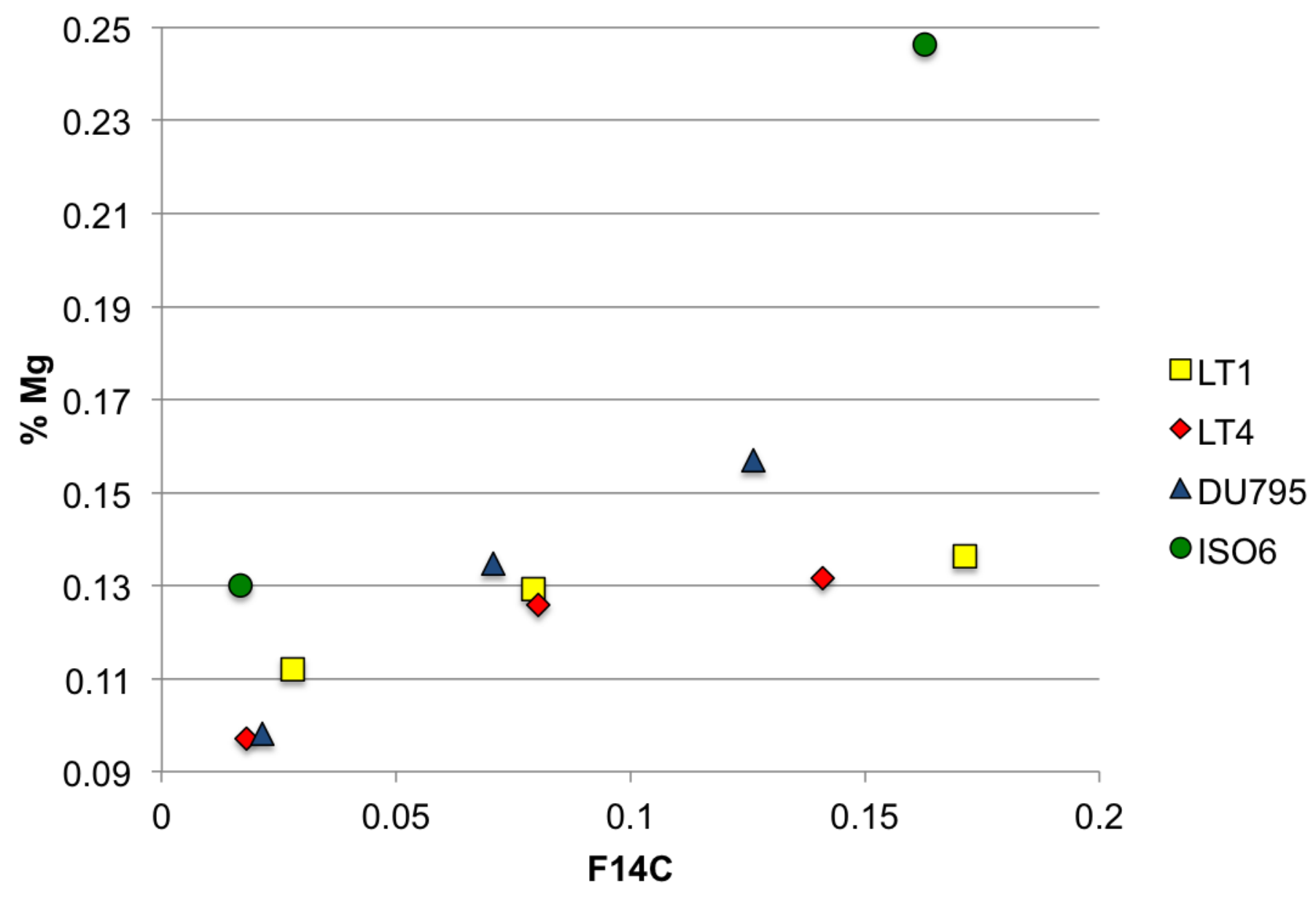




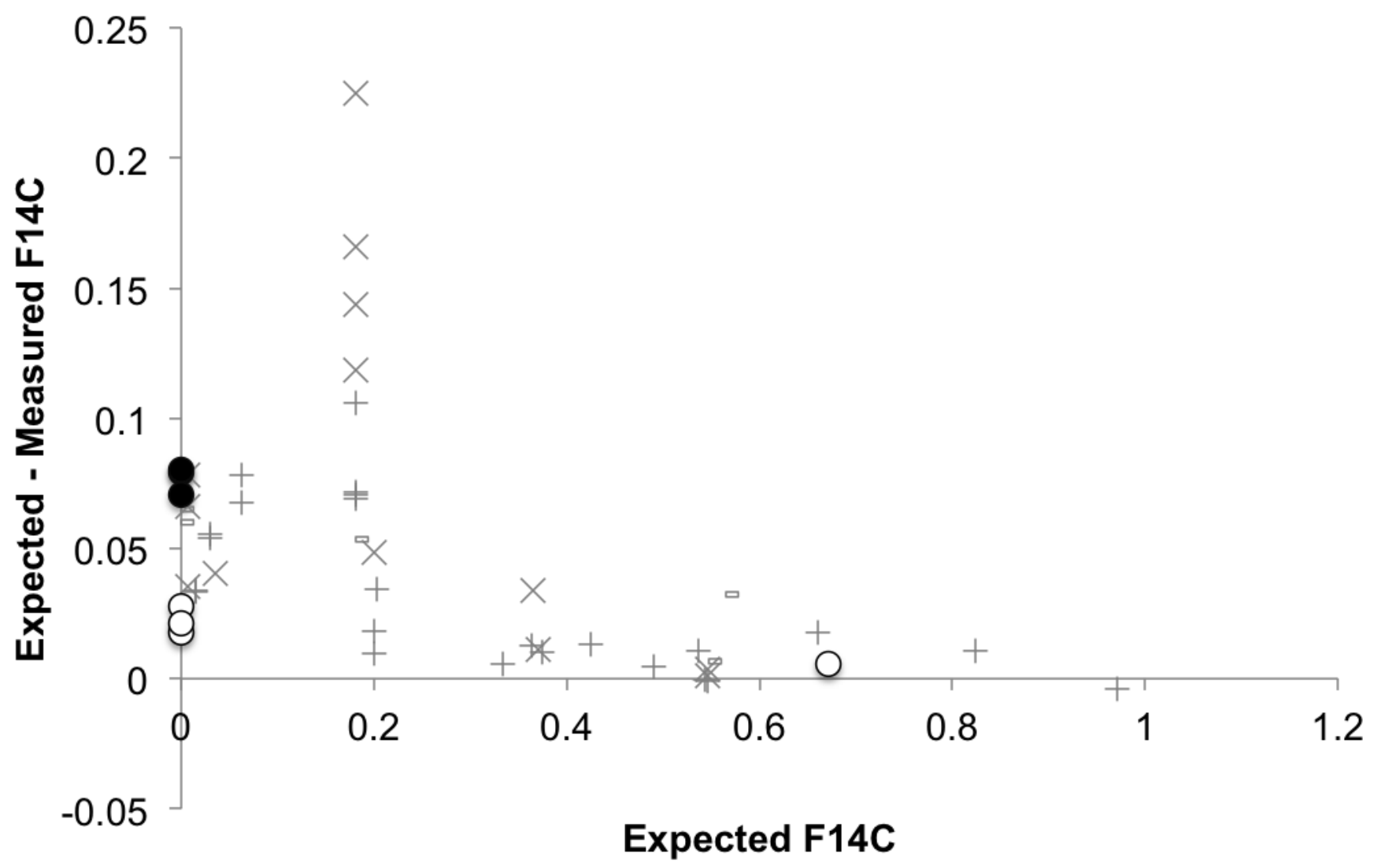

+ Bone apatite (Zazzo 2014)

-Dentine apatite (Zazzo 2014)

$\times$ Enamel apatite (Zazzo 2014)

- Hand ground_acid leach (this study)

OMicroniser_acid leach (this study) 